VOL: I NO: 1

\title{
PERENCANAAN STRATEGIS SISTEM INFORMASI DAN TEKNOLOGI
} INFORMASI PENDIDIK DAN KETENAGA PENDIDIKAN

\author{
Oleh : \\ Septian D Chandra ${ }^{1}$, Irfan Nur Afni ${ }^{2}$ \\ Dosen STMIK Dharma Wacana Metro Lampung ${ }^{1,2}$ \\ Email: Ip3m@stmikdharmawacana.ac.id website: http://ojs.stmikdharmawacana.ac.id
}

\section{Abstrak}

Perencanaan strategis sistem informasi dan teknologi informasi yang tepat dapat mendukung rencana dapat memperbaiki efisiensi kerja, Dinas Pendidikan Kebudayan Pemuda dan Olahraga (Disdikbudpora) Kota Metro sebagai institusi pendidikan di tingkat Kabupaten/Kota memiliki visi Pendidikan Unggul, berwawasan global dan berakhlak mulia, yang dijabarkan dalam misi dan tujuan strategis organisasi. Tujuan yang ingin dicapai adalah "layanan prima pendidikan". Hasil dari penelitianperencanaan strategis ini adalah tercapainya kesesuaian antara perencanaan strategi bisnis dengan perencanaan strategi SI/TI yang menjadi salah satu faktor penentu keberhasilan pengembangan sistem informasi bisnis di dalam organisasi. Proses perumusan perencanaan strategis SI dapat menghasilkan identifikasi sistem informasi yang dibutuhkan guna merealisasikan perencanaan strategis bisnis serta teknologi apa yang akan dikembangkan sehingga kebutuhan sistem informasi yang telah ditetapkan dapat terwujud.

\section{Kata kunci : Sistem informasi, Perancangan dan Analisa Sistem, Disdikbudpora Metro}

\section{Latar Belakang}

Sistem informasi (SI) merupakan senjata ampuh untuk meningkatkan efisiensi dan efektifitas dalam proses bisnis, oleh sebab itu hampir semua perusahaan memanfaatkan teknologi informasi (TI). Akan tetapi bila dilihat dari segi perencanaan, pengelolaan, dan implementasi maka dibutuhkan biaya yang mahal untuk menerapkan SI/TI sehingga perlu dilakukan perencanaan dan studi yang matang. Perencanaan strategis sistem informasi dan teknologi informasi yang tepat dapat mendukung rencana dapat memperbaiki efisiensi kerja dengan melakukan otomasi berbagai proses yang mengelola informasi, meningkatkan manajemen dengan memuaskan kebutuhan informasi guna pengambilan keputusan, serta memperbaiki daya saing atau meningkatkan keunggulan kompetitif organisasi dengan merubah gaya dan cara berbisnis. Dalam pelaksanaan aplikasi bisnis yang ideal, perencanaan strategis SI dan TI harus berjalan seiring dengan perencanaan strategis organisasi yaitu sesuai dengan tujuan, visi dan misi organisasi. Disdikbudpora Kota Metro belum secara optimal memanfaatkan TI dalam pencapaian tujuannya. Hal ini dikarenakan belum adanya mekanisme dalam menentukan prioritas kebutuhan untuk pengembangan aplikasi SI dan sarana infrastruktur TI. Agar penerapan sistem berbasis TIK dapat berjalan dengan optimal, diperlukan perumusan perencanaan strategis SI dan TI yang tepat pula. Perumusan perencanaan strategis dibuat dengan menggunakan versi Ward and Peppard karena dengan metode ini dapat melakukan analisis sesuai prioritas apakah terlebih dahulu melakukan analisis dari sisi lingkungan bisnis kemudian dari sudut SI/TI, atau sebaliknya. Metode ini dilakukan dengan tahapan menganalisis lingkungan organisasi bisnis dan SI/TI, baik internal maupun eksternal yang akan menghasilkan strategi SI berupa arsitektur sistem informasi, strategi manajemen SI/TI dan strategik TIK

Hasil dari penelitian perencanaan strategis ini adalah tercapainya kesesuaian antara perencanaan strategi bisnis dengan perencanaan strategi SI/TI yang menjadi salah satu faktor penentu keberhasilan pengembangan sistem informasi bisnis di dalam organisasi. Proses perumusan perencanaan strategis SI dapat menghasilkan identifikasi sistem informasi yang 
VOL: 1 NO: 1

dibutuhkan guna merealisasikan perencanaan strategis bisnis serta teknologi apa yang akan dikembangkan sehingga kebutuhan sistem informasi yang telah ditetapkan dapat terwujud

\subsection{Rumusan Masalah}

Berdasarkan latar belakang diatas maka dirumuskan permasalahan dalam penelitian ini adalah bagaimana merancang sebuah usulan rencana strategis sistem informasi dan teknologi informasi pendidik dan tenaga kependidikan yang tepat untuk diterapkan pada Dinas Pendidikan Kebudayan Pemuda dan Olahraga Kota Metro untuk tahun 2016-2021.

\subsection{Tujuan Penelitian}

Tujuan dari penelitian ini adalah merancang sebuah rencana strategis sistem informasi dan teknologi informasi pendidik dan tenaga kependidikan yang tepat untuk diterapkan pada Dinas Pendidikan Kebudayan Pemuda dan Olahraga Kota Metro untuk periode tahun 20162021

\subsection{Manfaat Penelitian}

a) Bagi Dinas Pendidikan Kebudayan Pemuda dan Olahraga Kota Metro dapat memberikan masukan dalam perumusan strategis SI dan TI pendidik dan tenaga kependidikan yang selaras dengan strategis bisnis organisasi.

b) Bagi STMIK Dharma Wacana dapat mengukur tingkat kematangan Dosen antara menyajikan materi dengan aplikatif dunia nyata.

c) Bagi peneliti dapat menambah wawasan, pengalaman serta menerapkan ilmu yang sudah didapat dari materi kuliah.

d) Bagi masyarakat luas dapat menambah khasanah keilmuan seputar IT dan perkembangannya.

\section{Teori Dasar}

\subsection{Perencanaan Strategis}

Rangkuti (2003, h.6) menyatakan "Perencanaan strategis adalah proses analisis kekuatankekuatan internal perusahaan dan kekuatan-kekuatan eksternal (peluang dan ancaman) suatu pasar, perumusan dan evaluasi strategi-strategi untuk mengatasi ancaman eksternal dan merebut peluang yang ada"

Pendapat lain oleh Gates (2010, p.3) mendefinisikan perencanaan strategis secara sederhana adalah sebagai berikut; "Strategic planning is the process of defining an organization's plans for achieving its mission". Perencanaan strategis adalah proses mendefinisikan rencanarencana organisasi untuk mencapai tujuannya.

Artinya perencanaan strategis bisnis merupakan proses untuk menyediakan arah dan sasaran jangka panjang bagi perusahaan sesuai dengan kekuatan internal serta menentukan strategistrategi untuk mengatasi ancaman eksternal sehingga dapat meningkatkan keunggulan bersaing perusahaan.

\subsection{Strategi Bisnis SI dan TI}

Strategi SI adalah proses mengidentifikasi portofolio aplikasi komputer yang akan diimplementasikan dan selaras dengan strategi organisasi dan mampu menciptakan keunggulan kompetitif organisasi. Strategi SI menentukan informasi dan sistem yang dapat mendukung strategi bisnis sesuai dengan kebutuhan organisasi. (Ward \& Peppard, 2002), Hubungan antara strategi bisnis, strategi SI dan strategi TI secara skematis menurut Ward (2002, p. 41) dapat dilihat pada gambar 2.1 berikut ini 


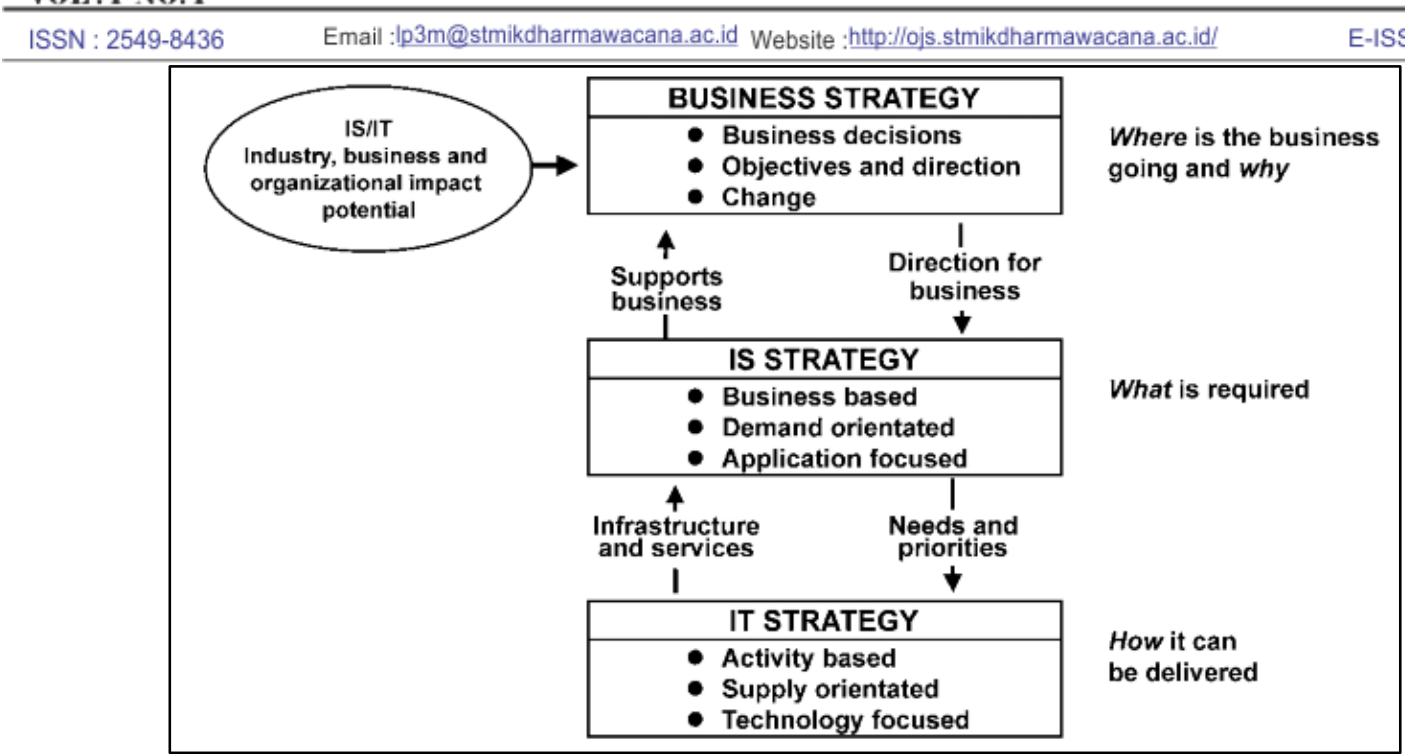

Gambar 2.1 Hubungan antara strategi bisnis, SI dan TI

\subsection{Kerangka Kerja Perencanaan Strategis SI dan TI}

Kerangka kerja perencanaan strategis SI dan TI menurut Ward ( 2002, p. 156-157) dimulai dari :

a. Memulai Proses Perencanaan

b. Mengetahui Kondisi Saat ini dan Peka Akan Kebutuhan Bisnis

c. Menentukan Strategi Bisnis Sistem Informasi dan Teknologi Informasi

d. Mendefinisikan Sistem Arsitektur dan Informasi

e. Merumuskan Proposal Teknologi Informasi

f. Menyiapkan Rencana Garis Besar, Kasus Bisnis dan Persetujuan Keuntungan. 


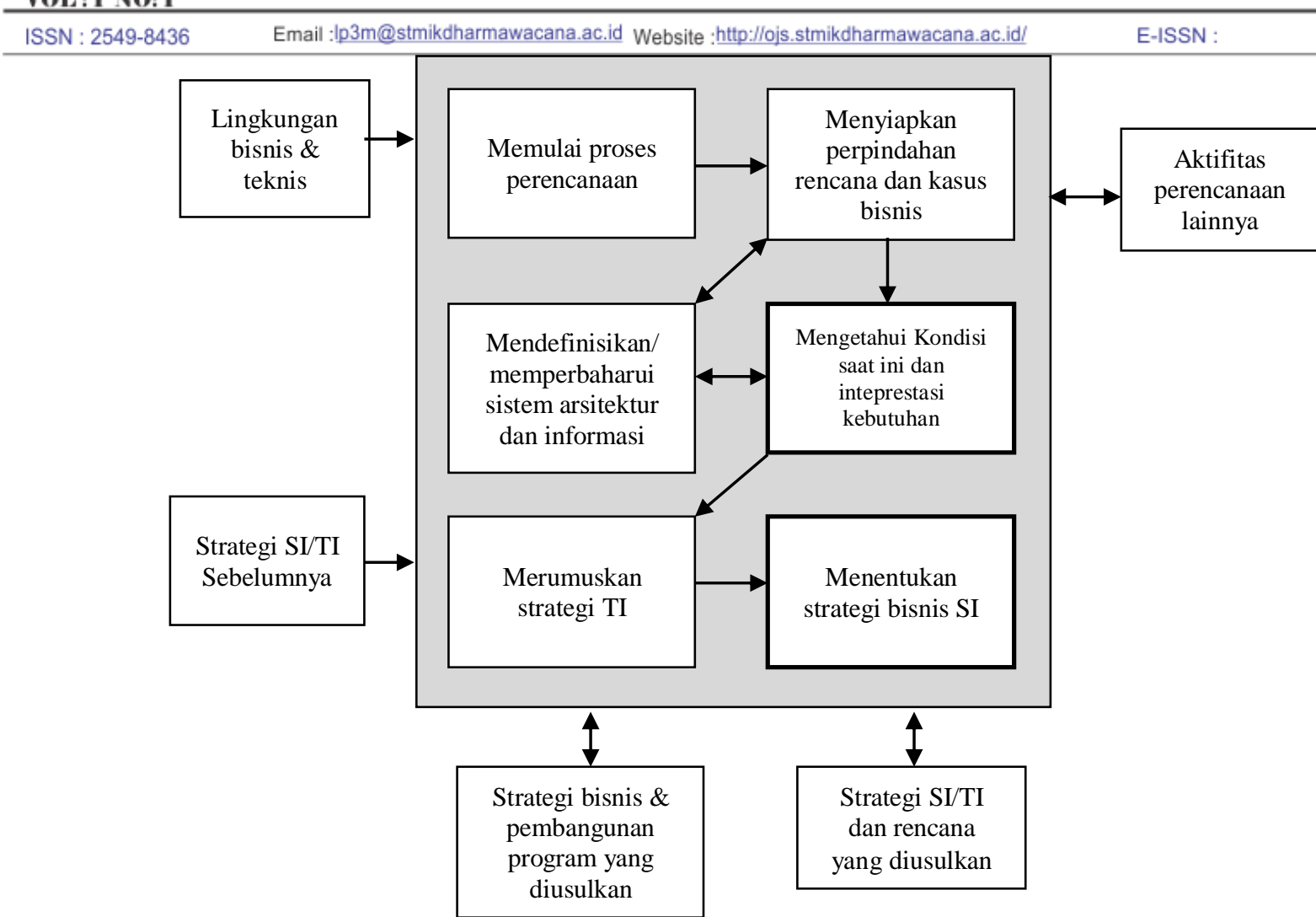

Gambar 2.2 Kerangka Kerja Proses Perencanaan Strategis SI dan TI

\subsection{Metodologi Perencanaan Strategis SI dan TI Versi Ward dan Peppard}

Faktor penting dalam proses perencanaan strategis SI dan TI adalah penggunaan metodologi. Metodologi merupakan kumpulan dari metode, teknik, dan tools yang digunakan untuk mengerjakan sesuatu. Tujuan dari penggunaan metodologi dalam perencanaan strategis SI dan TI adalah untuk "meminimalkan resiko kegagalan, memastikan keterlibatan semua pihak yang berkepentingan serta meminimalkan ketergantungan individu, dan lebih menekankan kepada proses dan sasaran yang ditentukan". Pendekatan metodologi versi Ward (2002, p. 154) ini dimulai dari kondisi investasi SI dan TI di masa sebelumnya yang kurang bermanfaat bagi tujuan bisnis organisasi dan menangkap peluang bisnis, serta fenomena meningkatkan keunggulan kompetitif suatu organisasi karena mampu memanfaatkan SI dan TI dengan maksimal. Kurang bermanfaatnya investasi SI dan TI bagi organisasi disebabkan karena perencanaan strategis SI dan TI yang lebih fokus ke teknologi, bukan berdasarkan kebutuhan bisnis. 


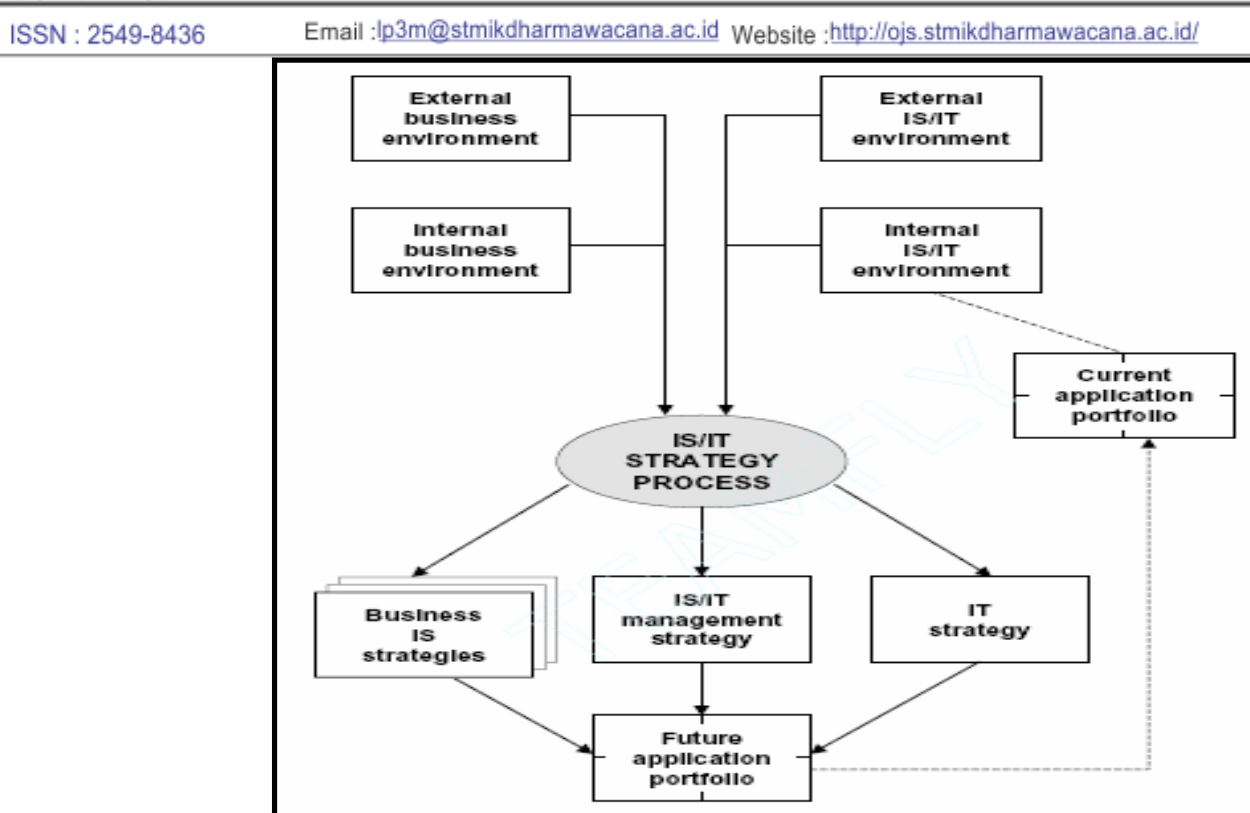

\subsection{Analisis SWOT}

Gambar 2.3 Perencanaan Strategis versi Ward dan Peppard

Menurut Tozer (1996), Analisis SWOT merupakan proses untuk menidentifikasi faktor internal (strength and weakness) dan faktor eksternal(opportunity and threat) dari organisasi secara sistematis untuk merumuskan strategi organisasi.

Analisis ini digunakan untuk mengevaluasi kekuatan (strength), kelemahan (weakness), peluang (opportunity), dan ancaman (threat) dalam suatu proyek atau suatu spekulasi bisnis. Proses ini melibatkan penentuan tujuan yang spesifik dari spekulasi bisnis atau proyek dan mengidentifikasi faktor internal dan eksternal yang mendukung dan yang tidak dalam mencapai tujuan tersebut.

a. Strength; faktor internal yang mendukung perusahaan dalam mencapai tujuannya. Faktor pendukung dapat berupa sumber daya, keahlian, atau kelebihan lain yang mungkin diperoleh berkat sumber keuangan, citra, keunggulan di pasar, serta hubungan baik antara buyer dengan supplier.

b. Weakness; faktor internal yang menghambat perusahaan dalam mencapai tujuannya. Faktor penghambat dapat berupa fasilitas yang tidak lengkap, kurangnya sumber keuangan, kemampuan mengelola, keahlian pemasaran dan citra perusahaan.

c. Opportunity; faktor eksternal yang mendukung perusahaan dalam mencapai tujuannya. Faktor eksternal yang mendukung dalam pencapaian tujuan dapat berupa perubahan kebijakan, perubahan persaingan, perubahan teknologi dan perkembangan hubungan supplier dan buyer.

d. Threat; faktor eksternal yang menghambat perusahaan dalam mencapai tujuannya. Faktor eksternal yang menghambat perusahaan dapat berupa masuknya pesaing baru, pertumbuhan pasar yang lambat, meningkatnya bargaining power daripada supplier dan buyer utama, perubahan teknologi serta kebijakan baru.

Menurut Rangkuti (2003) Sebelum menentukan strategi SO, ST, WO, dan WT terlebih dahuli dilakukan scoring yang menghasilkan jumlah total dari internal dan eksternal selanjutnya dimasukkan ke dalam kolom dibawah ini. 


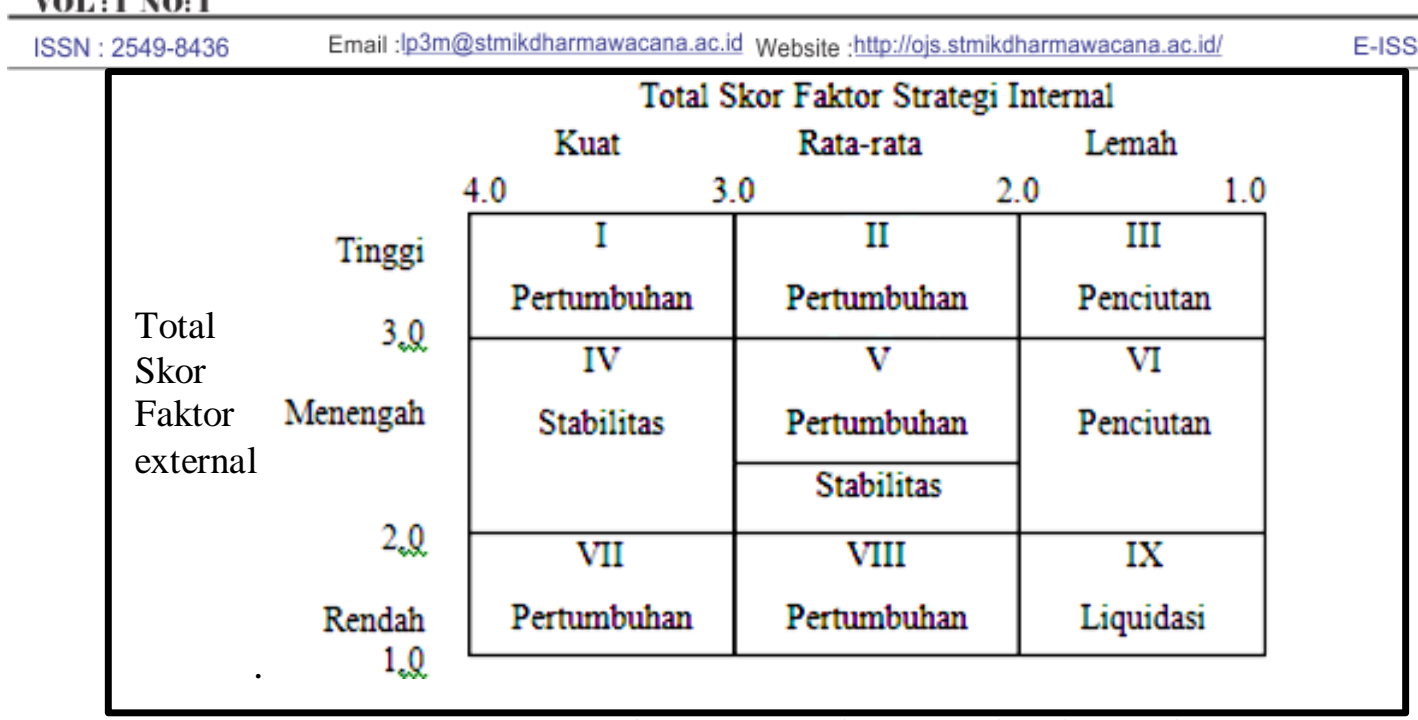

Gambar 2.4 Matriks Internal - Eksternal

Keterangan masing-masing kuadran :

I : Strategi konsentrasi melalui integrasi vertikal

II : Strategi konsentrasi melalui integrasi horizontal

III : Strategi turnaround

IV : Strategi stabilitas

V : Strategi konsentrasi melalui integrasi horizontal atau stabilitas

VI : Strategi divestasi

VII : Strategi diversifikasi konsentrik

VIII : Strategi diversifikasi konglomerat

IX : Strategi likuidasi atau bangkrut

\subsection{Analisis Value Chain}

Porter (1993) menyatakan bahwa analisis Value Chain digunakan untuk melakukan analisis lingkungan internal bisnis organisasi. Analisis ini akan memetakan seluruh proses kerja yang terjadi dalam organisasi menjadi dua kategori aktivitas, yaitu aktivitas utama dan aktivitas pendukung. Mengacu pada dokumen organisasi yang menyebutkan tugas dan fungsi setiap unit kerja dan berdasarkan pengamatan yang dilakukan terhadap proses kerja yang terjadi di masing-masing unit kerja.

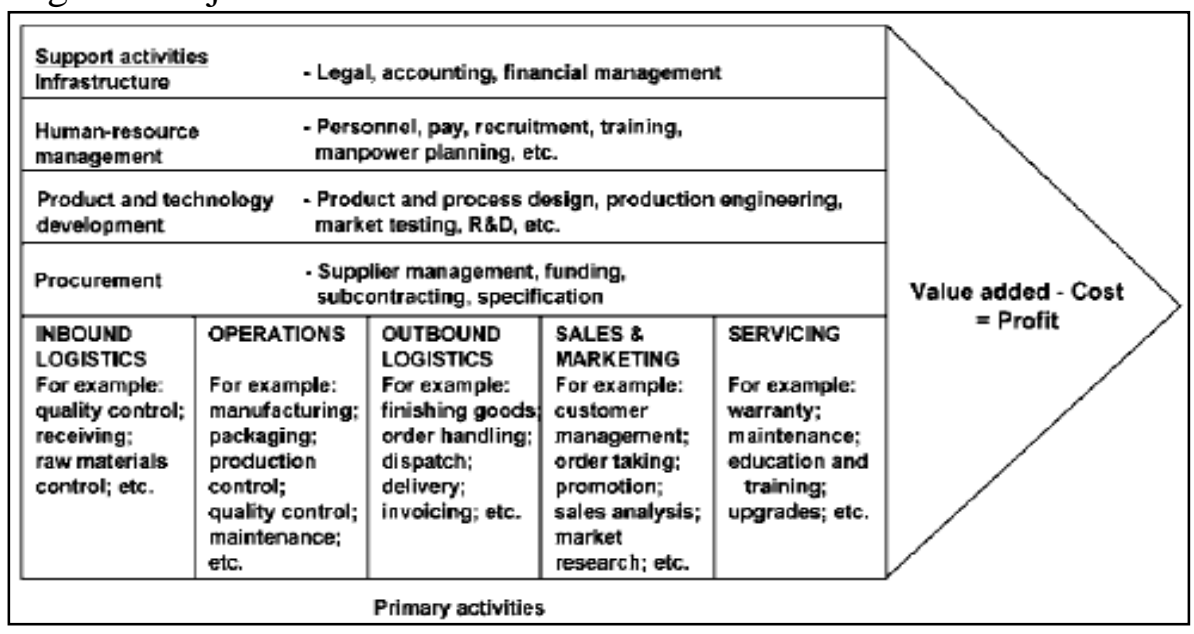

Gambar 2.5 Diagram Value Chain 
VOL: 1 NO: 1

2.7 Analisis Critical Success Factor

Menurut Rockart, yang dikutip oleh Ward (2002, p. 209-210) defenisi Critical Success Factor (CSF) "CSFs as being 'the limited number of areas in which result, if they are satisfactory, will ensure successful competitive perfonmance for the organitation". Sehingga peranan CSF dalam organsasi adalah sebagai penghubung antara strategi bisnis organisasi dengan strategi SI-nya, memfokuskan usaha organisasi pada area yang strategis, memprioritaskan usulan aplikasi SI, dan mengevaluasi strategi SI.

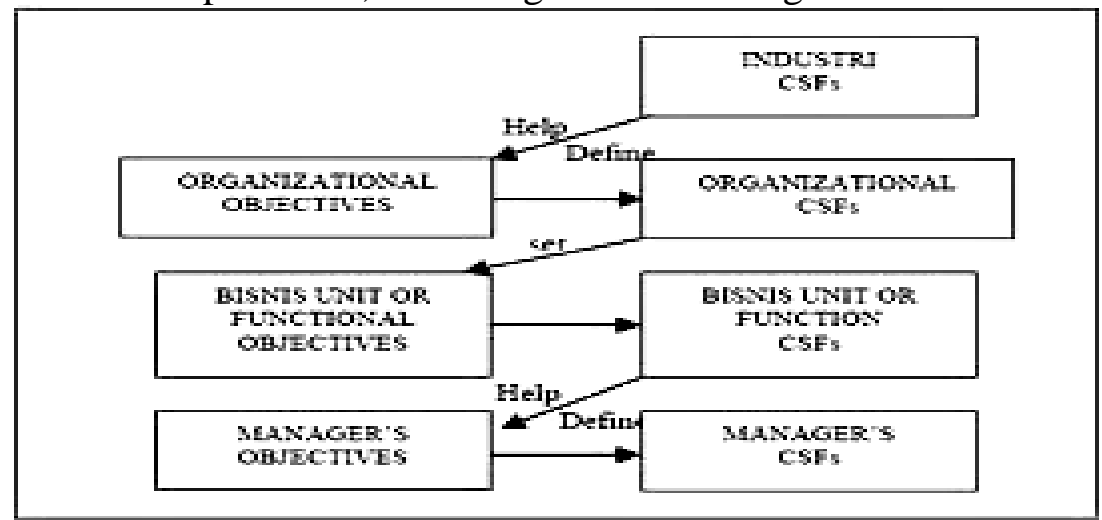

\subsection{Model Analisis PEST}

Gambar 2.6 Critical Success Factor

PEST adalah singkatan dari Politik, Ekonomi, Sosial dan Teknologi. Analisis ini digunakan untuk mengidentifikasi kondisi lingkungan umum atau lingkungan makro organisasi atau perusahaan. Identifikasi ini berdasarkan aspek politik dan hukum $(\mathrm{P})$, aspek Ekonomi $(\mathrm{E})$, aspek sosial dan budaya (S), dan aspek teknologi (T).

Pada Analisis PEST ada hubungan diantara semua kekuatan ini secara sigfinikan mempengaruhi semua produk, jasa, pasar dan organisasi di dunia. Oleh karena itu perusahaan harus mampu mengembangkan misi dan mendesain strategi untuk mencapai jangka panjang.

Dalam kerangka kerja yang lebih luas, perencanaan strategis tidak hanya dipengaruhi oleh faktor di atas, tetapi ada faktor-faktor lainnya seperti: legalitas, ekologi, dan faktor-faktor lainnya, seperti digambarkan pada strategic framework Ward $(2002,71)$, sebagai berikut :

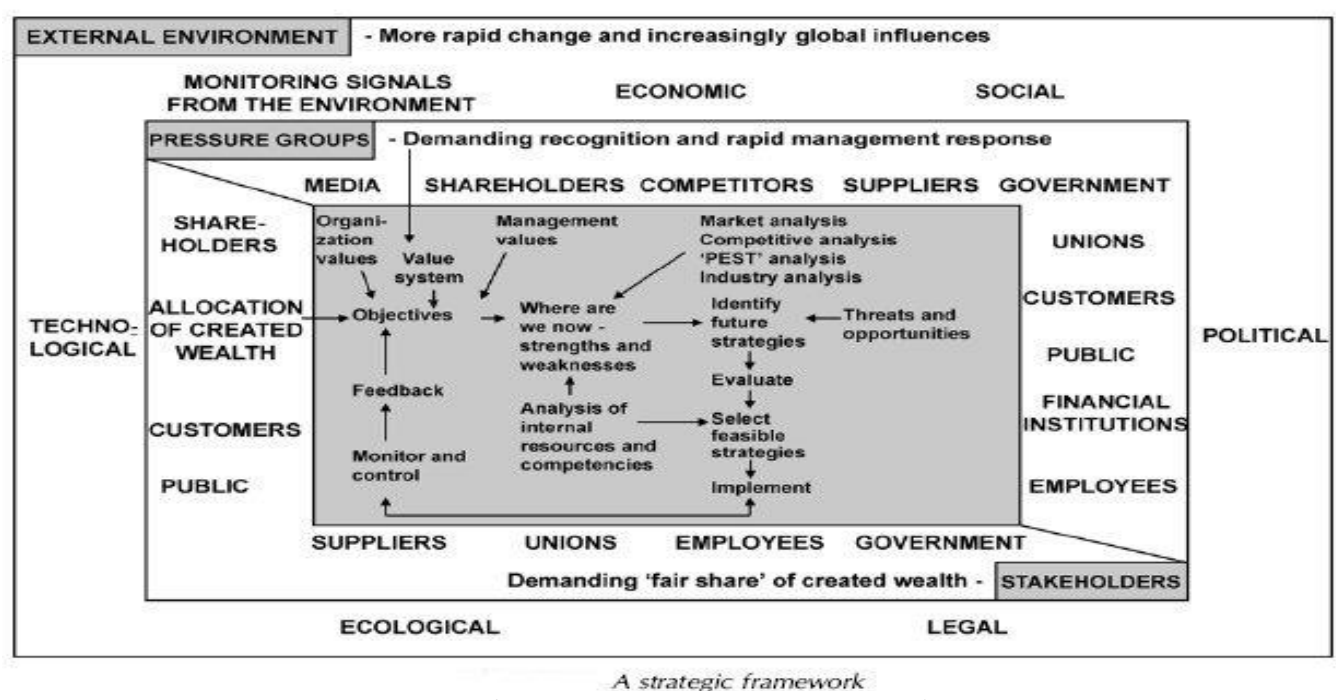

Gambar 2.7 Strategic Framework

\subsection{Analisis Mc Farlan Strategic Grid}


VOL: 1 NO: 1

Menurut Ward (2002) Analisis aplikasi portofolio digunakan untuk memetakan aplikasi yang ada saat ini dan juga kebutuhan aplikasi dimasa akan datang dalam mendukung bisnis organisasi/perusahaan. Pemetaan aplikasi menurut McFarlan ada empat kuadran yaitu : strategic, high potential, key operation, and support, sesuai kategori penilaian suatu aplikasi terhadap dampaknya terhadap bisnis. Dari hasil pemetaan tersebut didapatkan gambaran kontribusi SI/TI terhadap bisnis. Hasil tersebut dapat menjadi masukan bagi kegiatan pembuatan strategi SI dan kemungkinan pengembangannya ke depan.

Tabel 2.1 McFarlan Strategic Grid

\begin{tabular}{|c|c|}
\hline $\begin{array}{c}\text { STRATEGIC } \\
\text { Aplikasi-aplikasi yang sangat } \\
\text { rentan terhadap } \\
\text { keberlangsungan proses } \\
\text { bisnis intitusi }\end{array}$ & $\begin{array}{c}\text { HIGH POTENTIAL } \\
\text { Aplikasi-aplikasi yang menjadi } \\
\text { potensial dalam upaya } \\
\text { meningkatkan kemajuan yang } \\
\text { akan datang }\end{array}$ \\
\hline $\begin{array}{c}\text { KEY OPERATIONAL } \\
\text { Aplikasi-aplikasi ini menjadi } \\
\text { bergantungnya kesuksesan } \\
\text { bagi institusi }\end{array}$ & $\begin{array}{c}\text { SUPPORT } \\
\text { Aplikasi-aplikasi yang } \\
\text { berharga namun tidak } \\
\text { menjadikan bergantungnya } \\
\text { kesuksesan intitusi }\end{array}$ \\
\hline
\end{tabular}

\subsection{Tinjauan Penelitian}

Beberapa penelitian tentang perencanaan strategik SI/TI memperlihatkan tentang latar belakang dan permasalahan mengapa perencanaan strategik sistem informasi perlu untuk disusun sebagai pedoman dalam pengelolaan sistem informasi saat ini dan untuk di masa yang akan datang. Berikut adalah ringkasan tentang perencanaan strategik sistem informasi dari hasil beberapa penelitian:

a. Perencanaan Strategis SI/TI digunakan untuk menyelaraskan antara kebutuhan strategi bisnis dan strategi SI/TI untuk mendapatkan nilai tambah dari suatu organisasi dari segi keunggulan kompetitif. Metodologi Ward and Peppard dengan teknik/metode analisis yang digunakan mencakup analisis SWOT, analisis Five Forces Competitive, analisis Value Chain, metode Critical Succes Factors, metode Balanced Scorecard, dan McFarlan's Strategic Grid. (Wedhasmara, 2012). Bagian dari penelitian ini yang akan diadopsi adalah metode yang digunakan serta langkahlangkah analisa.

b. Pengembangan Sistem Informasi dan Teknologi Informasi (SI/TI) membutuhkan perencanaan yang matang untuk menghindari kerugian yang lebih besar dari sisi finansial dan investasi. Pengembangan SI/TI yang tidak sistematis akan terkesan tambal sulam, memenuhi kebutuhan sesaat, tidak ada skala prioritas dan tidak sesuai dengan irama bisnis organisasi. Dalam penelitiannya Pipin menggunakan pendekatan perencanaan menurut Ward dan Peppard dengan beberapa metode analisis antara lain value chain, five force model, dan Critical Success Factors.). Hasil penelitiannya adalah blue print perencanaan strategis yang mengacu pada rencana bisnis organisasi berdasarkan data yang diperoleh melalui metode analisis yang digunakan serta melibatkan seluruh komponen organisasi. (Widyaningsih, 2012). Bagian dari penelitian ini yang akan diadopsi adalah pendekatan perencanaan dan metode yang digunakan untuk menghasilkan sebuah blue print perencanaan strategis. 
c. Dengan perencanaan strategis SI/TI akan diperoleh keuntungan empat hal : pertama tersedianya informasi yang lebih baik dalam upaya pemerataan dan perluasan akses pendidikan, kedua terwujudnya peran TIK yang optimal dalam rangka peningkatan mutu pendidikan, ketiga relevansi dan daya saing organisasi, keempat terwujudnya penguatan tata kelola, akuntabilitas dan pencitraan publik dengan penerapan TIK. Metodologi yang dikemukakan adalah Metodologi John Ward dan Joe Peppard. Metode penelitian yang dilakukan yakni antara lain studi pustaka, melakukan pengamatan langsung terhadap kegiatan dan adminstrasi serta studi literatur mengkaji dan menganalisis landasan teori yang sesuai untuk digunakan dalam menyusun kerangka kerja rencana strategis SI/TI. Simpulan penelitian adalah penyusunan perencanaan strategis SI/TI sesuia portofolio SI/TI yang dihasilkan dapat memberikan prioritas pada aktivitas yang dibutuhkan untuk memperoleh hasil yang optimal dan berdasarkan kontribusinya pada tujuan yang akan dicapai (Sihombing, 2012). Bagian dari penelitian ini yang akan diadopsi adalah tahapan analisis data digunakan untuk menghasilkan sebuah blue print perencanaan strategis pada dinas pendidikan.

d. Dengan adanya perencanaan strategis sistem informasi membantu dalam melaksanakan tugas pokok dan fungsi serta meningkatkan nilai. Peran TI dalam mendukung pencapaian Renstra dapat bersifat strategis sehingga diperlukan solusi untuk menemukan gap antara SI/TI yang telah dimiliki dengan yang seharusnya ada. adalah mengidentifikasi gambaran umum. Lalu menganalisis lingkungan bisnis dengan analisis PEST, analisis SWOT, analisis proses statistik yang berjalan, serta memetakan fungsi terhadap subyek data yang berkaitan. Selanjutnya, analisis lingkungan SI/TI dengan mengevaluasi kinerja divisi TI berdasarkan perspektif IT BSC, mendata infrastruktur SI/TI yang dimiliki dan standar teknologi yang digunakan, menganalisis keamanan aset yang dimiliki, memetakan kategori aplikasi yang dimiliki saat ini serta menganalisis perkembangan teknologi yang dapat digunakan untuk meningkatkan kinerja. (Anggelina, 2012)

e. Setelah melakukan analisis-analisis maka diidentifikasi masalah-masalah utama yang dihadapi. Kemudian analisis gap dilakukan untuk melihat kondisi saat ini dan sasaran dari sistem yang diharapkan. Dari hasil analisis gap dan analisis lingkungan bisnis dan SI/TI dilihat dari kebutuhan aplikasi, kemudian disusun perencanaan strategis sistem. (Anggelina, 2012) Bagian dari penelitian ini yang akan diadopsi adalah metode penelitian yang dilakukan untuk menghasilkan sebuah blue print perencanaan strategis.

\subsection{Tinjauan Objek Penelitian}

\subsubsection{Gambaran Umum Dinas Pendidikan Kebudayan Pemuda dan Olahraga Kota Metro}

Disdikbudpora mempunyai tugas pokok mengatur urusan pemerintah daerah di bidang pendidikan, bidang kebudayaan, bidang pemuda dan olahraga selanjutnya menyusun rencana pengembangan Pendidikan Dasar, Menengah, dan pendidikan nonformal informal sebagai acuan dalam menyusun rencana kerja tahunan Satuan Kerja Perangkat Daerah pada Disdikbudpora Kota Metro

Dinas Pendidikan Kebudayaan Pemuda dan Olahraga Kota Metro mengelola 12 Perguruan Tinggi dan 183 buah sekolah mulai dari jenjang Taman Kanak-Kanak hingga Menengah dan Kejuruan serta berbagai sarana pendidikan non formal lainnya.

\section{Metodologi Penelitian}


VOL: 1 NO: 1

3.1 Metode Pengumpulan Data

Data yang diperlukan dalam penyusunan perencanaan strategis SI/TI pada Disdikbudpora Kota Metro ini meliputi data yang terkait dengan model proses bisnis organisasi, peluang dan kelemahan penerapan teknologi informasi, kekuatan dan peluang pemanfaatan teknologi informasi, tugas pokok dan fungsi Satuan Kerja Perangkat Daerah. Data yang diperlukan dalam penyusunan perencanaan strategis SI/TI ini dikumpulkan melalui :

a. Wawancara

Wawancara dilakukan secara terbuka dimana informan yang berfungsi sebagai pihak yang diwawancarai mengetahui keberadaan peneliti sebagai pewawancara di lokasi penelitian. Sebelum melakukan wawancara, terlebih dahulu dilakukan pemilihan informan yang akan diwawancarai sebagai key person dari objek tempat dilakukannya penelitian sebagaimana dapat dilihat pada tabel 3.1. Daftar pertanyaan dibuat dalam bentuk clustering pada bagian organisasi, sumber daya manusia (SDM), kondisi ekternal organisasi serta infrastruktur seperti pada gambar 3.1. Adapun daftar wawancara terlampir.

Tabel. 3.1 Kebutuhan Data dan Sumber Data

\begin{tabular}{|c|c|}
\hline Jenis Kebutuhan Data & Sumber Data \\
\hline Profil Organisasi & Ka Disdikbudpora Kota Metro \\
\hline Keuangan & Sub Bag Keuangan \\
\hline $\begin{array}{l}\text { Penataan dan Pemerataan } \\
\text { PTK }\end{array}$ & $\begin{array}{l}\text { Dokumen Juknis Peraturan } 5 \\
\text { Menteri }\end{array}$ \\
\hline Data PTK & Seksi PTK dikdas dan Dikmen \\
\hline Data Sarana Prasarana & Subbag Perencanaan, observasi \\
\hline Data Peserta Didik & $\begin{array}{l}\text { Seksi Kelembagaan Dikdas, Seksi } \\
\text { Kelembagaan Dikmen }\end{array}$ \\
\hline Perkembangan SI/TI & Internet \\
\hline $\begin{array}{l}\text { Aspek Politik, Ekonomi, } \\
\text { Sosial, Teknologi }\end{array}$ & $\begin{array}{l}\text { Observasi pada proses penerapan } \\
\text { SI/TI di lingkup Disdikbudpora dan } \\
\text { Website disdik.metrokota.go.id serta } \\
\text { metrokota.go.id }\end{array}$ \\
\hline
\end{tabular}




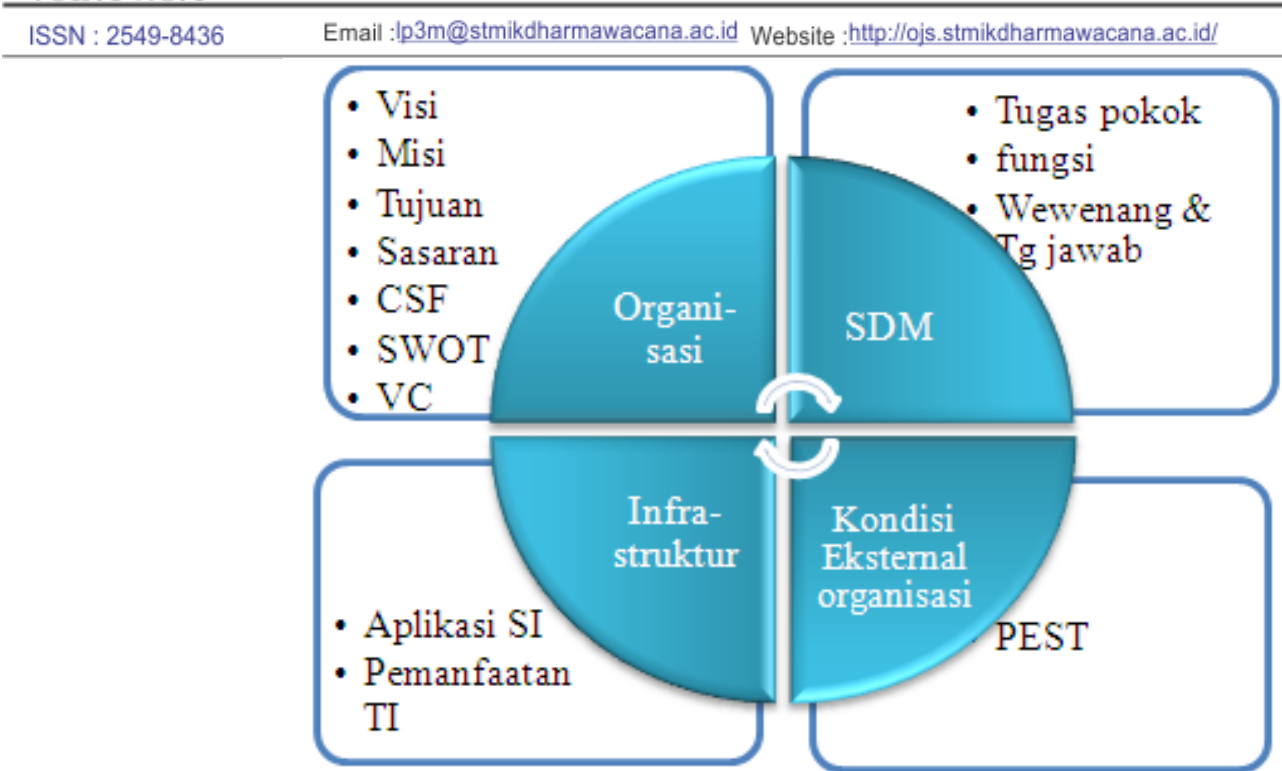

Gambar 3.1 Klasifikasi Daftar Pertanyaan

b. Observasi

Metode observasi digunakan untuk menghimpun data penelitian melalui pengamatan dan penginderaan. Peneliti melakukan observasi dengan mengamati proses bisnis yang ada di Disdikbudpora Kota Metro.

Observasi yang akan dilakukan adalah observasi terhadap subjek, perilaku subjek selama wawancara, interaksi subjek dengan peneliti dan hal-hal yang dianggap relevan sehingga dapat memberikan data tambahan terhadap hasil wawancara.

c. Studi Literatur

Studi literatur dilakukan peneliti dengan mempelajari berbagai dokumen/referensi yang terkait dengan objek penelitian dan perkembangan SI/TI.

\subsection{Analisis dan Interpretasi Data}

Mengacu pada kerangka kerja Perencanaan SI/TI versi Ward dan Peppard(Ward 2002, p.157), maka tahapan analisa pada penelitian ini dibagi menjadi empat tahap yaitu : tahap ke1 analisis kebutuhaan bisnis dan Informasi, tahap ke-2 proses identifikasi target SI/TI, tahap ke-3 proses identifikasi strategi SI/TI, tahap ke-4 merancang portofolio mendatang, seperti pada gambar 3.2 halaman berikut.

Data-data yang telah dikumpulkan kemudian akan dilakukan analisis dan diinterpretasikan dengan langkah-langkah seperti pada gambar 3.3, mulai dari identifikasi organisasi, analisis lingkungan bisnis internal, analisis lingkungan bisnis external, analisis lingkungan SI.TI internal, analisis lingkungan SI.TI external, analisis gap kebutuhan informasi, membuat landasan kebijakan, kemudian membuat strategi SI/TI hingga merancang portofolio 
VOL: I NO: 1

mendatang dan masing-masing akan menghasilkan output hingga aplikasi portofolio mendatang.

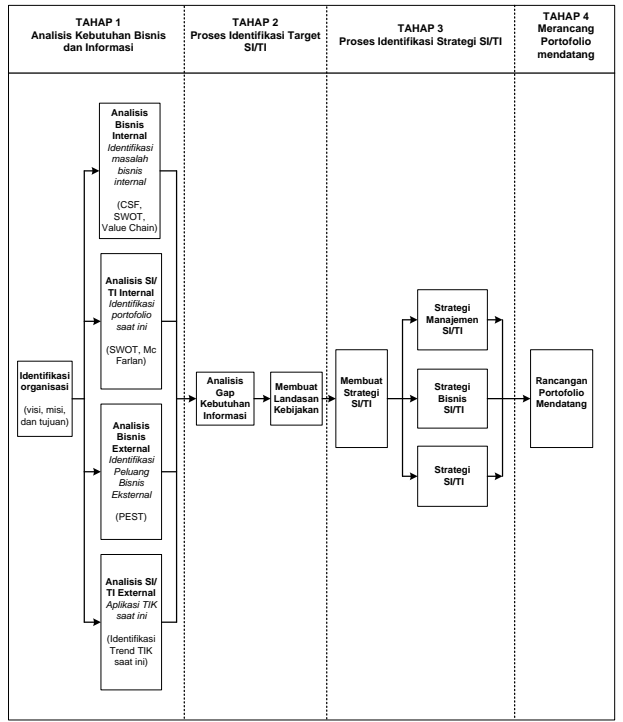

Gambar 3.2. Kerangka Kerja Perencanaan SI/TI

\section{Hasil dan Pembahasan}

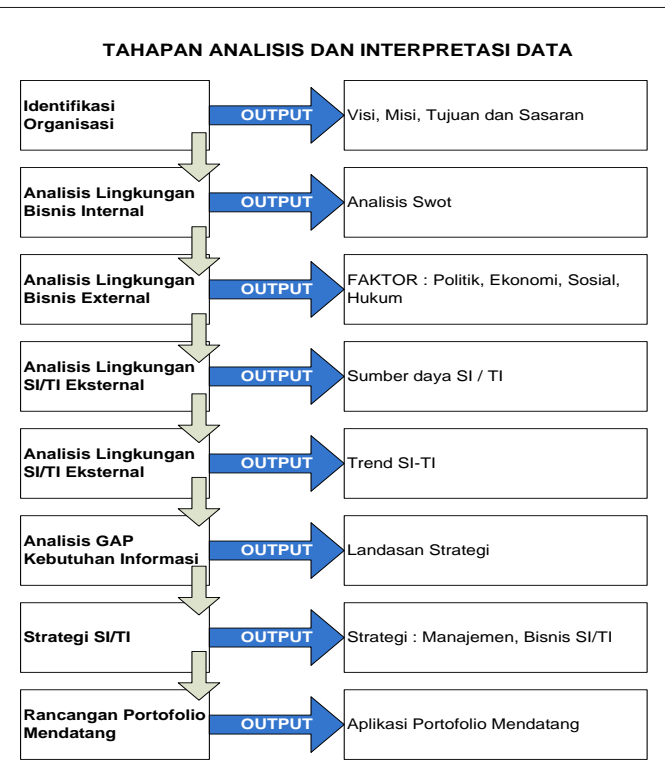

Gambar 3.3 Tahapan Analisis dan Interpretasi Data

\subsection{Identifikasi Organisasi}

Disdikbudpora mempunyai tugas pokok mengatur urusan pemerintah daerah di bidang pendidikan, bidang kebudayaan, bidang pemuda dan olahraga dan menyusun rencana pengembangan Pendidikan Dasar, Menengah, dan pendidikan nonformal informal sebagai acuan dalam menyusun rencana kerja tahunan Satuan Kerja Perangkat Daerah pada Disdikbudpora Kota Metro

Dinas Pendidikan Kebudayaan Pemuda dan Olahraga Kota Metro mengelola 12 Perguruan Tinggi dan 201 buah sekolah mulai dari jenjang Taman Kanak-Kanak hingga Menengah dan Kejuruan serta berbagai sarana pendidikan non formal lainnya.

\subsection{Sumber Daya Pendidikan}

Tabel 4.1 Data Satuan Pendidikan Tahun 2013 
YOL: 1 NO: 1

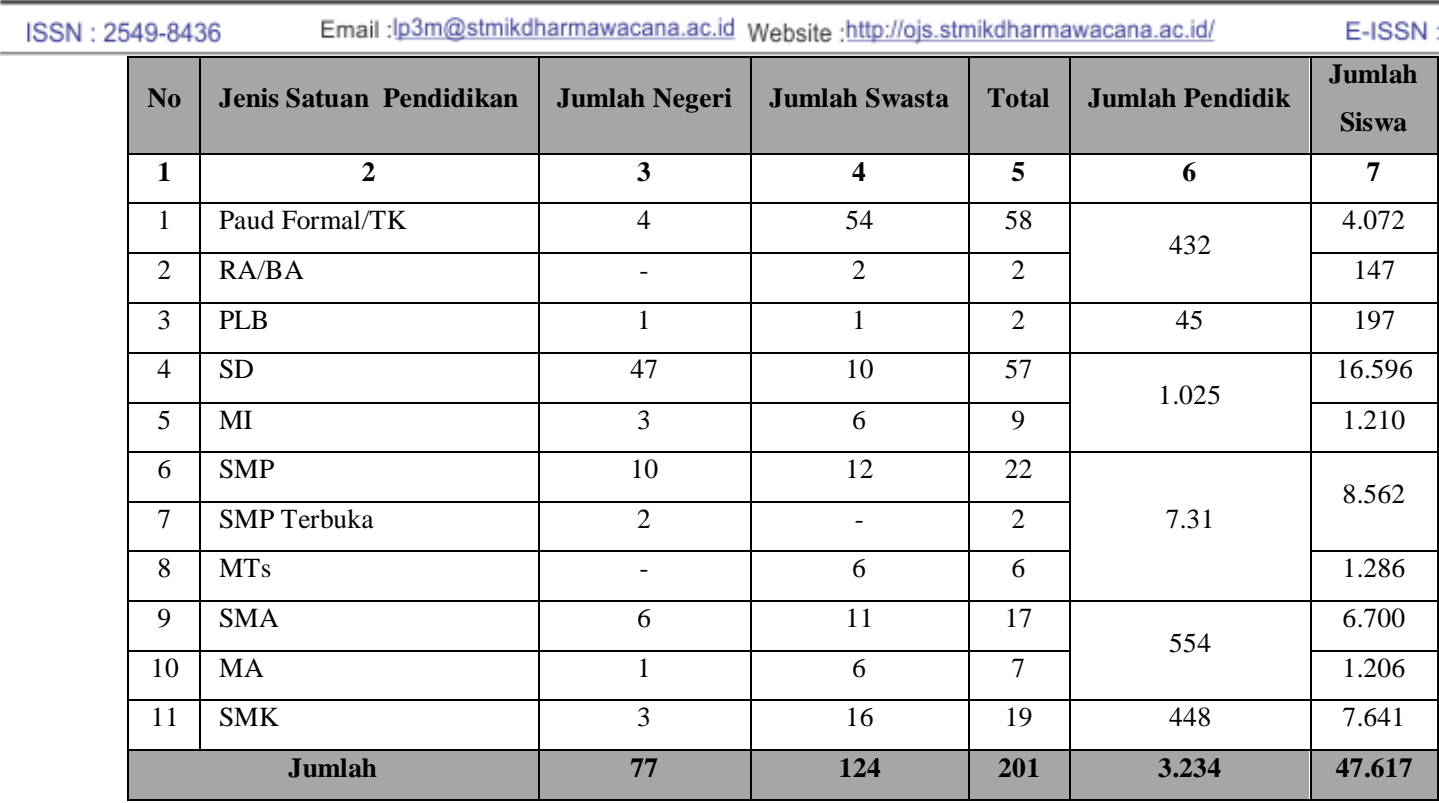

\subsection{Analisis Bisnis Internal}

Analisis pada tahap ini merupakan tahapan penting dalam perencanaan strategis SI/TI Pendidik karena menentukan cakupan perencanaan strategis SI/TI dan memberikan dasar bagi perumusan strategi SI/TI.

a. Analisis Critical Success Factor (CSF)

Identifikasi CSF terhadap tujuan strategis Disdikbudpora Kota Metro dilakukan melalui proses pemilihan tujuan yang memiliki keterkaitan dengan pemerataan dan peningkatan pendidik untuk menemukan kebutuhan TIK dari organisasi.

Identifikasi CSF terhadap tujuan Disdikbudpora Kota Metro dapat dilihat pada tabel berikut.

Tabel 4.2 Tujuan dan CSF Disdikbudpora Kota Metro Bidang Pendidikan

\begin{tabular}{|l|l|l|}
\hline Tujuan & CSF & Prime Measure \\
\hline $\begin{array}{l}\text { Pemeraatan dan peningkatan } \\
\text { SDM PTK }\end{array}$ & $\begin{array}{l}\text { Pemeraatan dan } \\
\text { peningkatan SDM PTK }\end{array}$ & $\begin{array}{l}\text { Peningkatan ketersediaan tenaga pendidik PAUD, TK, SD, SMP, } \\
\text { SMA/SMK yang bersertifikasi dan berkualifikasi }\end{array}$ \\
\hline $\begin{array}{l}\text { Meningkatkan kualitas sarana } \\
\text { prasarana pendidikan }\end{array}$ & $\begin{array}{l}\text { Jumlah sarana-prasarana } \\
\text { pendidikan }\end{array}$ & Penyediaan sarana-prasarana pendidikan \\
\hline $\begin{array}{l}\text { Meningkatkan kualitas } \\
\text { manajemen pendidikan }\end{array}$ & $\begin{array}{l}\text { Penguatan Manajemen } \\
\text { satuan pendidikan }\end{array}$ & $\begin{array}{l}\text { Penguatan kualitas manajemen lembaga/satuan pendidikan } \\
\text { formal dan non formal }\end{array}$ \\
\hline
\end{tabular}

Berdasarkan tabel di atas, dapat diketahui bahwasanya pencapaian tujuan-tujuan organisasi Dinas Pendidikan Kebudayaan Pemuda dan Olahraga Kota Metro dipengaruhi oleh business need yang tertuang pada tabel di atas, selanjutnya untuk mengetahui kebutuhan TIK yang mendukung business need organisasi dalam bidang pendidikan, maka perlu dilakukan elaborasi terhadap CSF organisasi dengan menentukan Key Decision yang berhubungan dengan CSF tersebut, dan dari Key Decision tersebut akan diidentifikasi kebutuhan TIK dari organisasi. Hasil elaborasi CSF dapat dilihat pada tabel 4.3 di bawah ini.

Tabel 4.3 Identifikasi Kebutuhan TIK

$$
\begin{array}{|l|l|l|l}
\hline \text { No } & \text { CSF } & \text { Key Decision } & \text { Kebutuhan Informasi } \\
\hline
\end{array}
$$


VOL: 1 NO: 1

\begin{tabular}{|c|c|c|c|}
\hline \multicolumn{4}{|c|}{ Email:lp3m@stmikdharmawacana.ac.id Website :http://ojs.stmikdharmawacana.ac.id/ } \\
\hline No & CSF & Key Decision & Kebutuhan Informasi \\
\hline 1 & $\begin{array}{l}\text { Pemeraatan dan } \\
\text { peningkatan SDM } \\
\text { PTK }\end{array}$ & $\begin{array}{l}\text { Peningkatan ketersediaan tenaga } \\
\text { pendidik PAUD, TK, SD, SMP, } \\
\text { SMA/SMK yang bersertifikasi dan } \\
\text { berkualifikasi. }\end{array}$ & $\begin{array}{l}\text { - Informasi PTK } \\
\text { - Informasi PKB } \\
\text { (Pengembangan } \\
\text { Keprofesian } \\
\text { Berkelanjutan) }\end{array}$ \\
\hline & $\begin{array}{l}\text { Jumlah sarana- } \\
\text { prasarana } \\
\text { pendidikan }\end{array}$ & Penyediaan sarana-prasarana pendidikan & $\begin{array}{l}\text { - Informasi Pemetaan } \\
\text { Sekolah }\end{array}$ \\
\hline 3 & $\begin{array}{l}\text { Penguatan } \\
\text { Manajemen satuan } \\
\text { pendidikan }\end{array}$ & $\begin{array}{l}\text { Penguatan kualitas manajemen } \\
\text { lembaga/satuan pendidikan formal } \\
\text { dan non formal } \\
\text { - Peningkatan mutu layanan } \\
\text { pendidikan }\end{array}$ & $\begin{array}{l}\text { - Profil sekolah } \\
\text { - Informasi Siswa dan } \\
\text { Akademik }\end{array}$ \\
\hline
\end{tabular}

\subsection{Analisis SWOT}

Sebelum menentukan strategi SO, ST, WO, dan WT terlebih dahulu dilakukan scoring dengan menggunakan matrik IFAS dan EFAS. Berikut adalah matrik Internal Strategic Factors Analysis Summary (IFAS) dapat dilihat pada tabel 4.3 dan matrik Eksternal Strategic Factors Analysis Summary (EFAS) dapat dilihat pada tabel 4.4 dimana bobot ditentukan dengan skala 0,0 (tidak penting) sampai 1,0 (sangat penting) berdasarkan kemungkinan dampak yang dihasilkan terhadap faktor strategis. Selanjutnya rating ditentukan dengan skala mulai 4 (outstanding) sampai 1 (poor) berdasarkan pengaruh faktor tersebut terhadap kondisi organisasi, penentuan rating untuk kelemahan dan ancaman dilakukan sebaliknya (Rangkuti 2003, p.24).

Tabel 4.4 Matrik Internal Strategic Factors Analysis Summary (IFAS)

\begin{tabular}{|c|c|c|c|c|}
\hline Faktor-Faktor Strategi Internal & Bobot & Rating & \begin{tabular}{|c|} 
Bobot \\
$\mathbf{x}$ \\
Rating
\end{tabular} & Komentar \\
\hline $\begin{array}{l}\text { Kekuatan (S) : } \\
\text { 1. Memiliki Tupoksi sebagai pedoman kerja } \\
\text { 2. Tupoksi Dinas yang selaras dengan visi, misi, dan tujuan pembangunan } \\
\text { daerah } \\
\text { 3. SDM dengan kedisiplinan dan kemauan yang tinggi dalam pelaksanaan } \\
\text { tupoksi } \\
\text { 4. Keberadaan Komite sekolah, dewan sekolah dan masyarakat yang } \\
\text { menunjang pelaksaaan pendidikan } \\
\text { 5. Adanya dana / pembiayaan dari masyarakat }\end{array}$ & $\begin{array}{l}0,15 \\
0,10 \\
0.05 \\
0.05\end{array}$ & $\begin{array}{l}3 \\
2 \\
1\end{array}$ & $\begin{array}{l}0,60 \\
0,30 \\
0.1 \\
0.05\end{array}$ & $\begin{array}{l}\text { Mempengaruhi kesuksesan } \\
\text { Arah pencapaian tujuan } \\
\text { Kekuatan SDM } \\
\text { Pendukung } \\
\text { Pendukung }\end{array}$ \\
\hline \begin{tabular}{ll}
\multicolumn{2}{l}{ Kelemahan $(\mathbf{W})$ : } \\
1. & Belum adanya pedoman pengembangan SI/TI \\
2. & Kurangnya SDM dalam bidang SI/TI \\
3. & Terbatasnya anggaran pengembangan SI/TI \\
4. & \\
5. & Pelum adanya pusat pengolahan data dan sumber belajar \\
\end{tabular} & $\begin{array}{l}0,15 \\
0,05 \\
0,10 \\
0,15 \\
0.05\end{array}$ & $\begin{array}{l}1 \\
2 \\
3 \\
1\end{array}$ & $\begin{array}{l}0,30 \\
0,05 \\
0,20 \\
0,45 \\
0.05\end{array}$ & $\begin{array}{l}\text { Perlu dibuat } \\
\text { Perlu penambahan } \\
\text { Perlu diperhatikan\& } \\
\text { ditingkatkan } \\
\text { Perlu dibuat } \\
\text { Perlu diperhatikan }\end{array}$ \\
\hline
\end{tabular}


Tabel 4.5 Matrik Eksternal Strategic Factors Analysis Summary (EFAS)

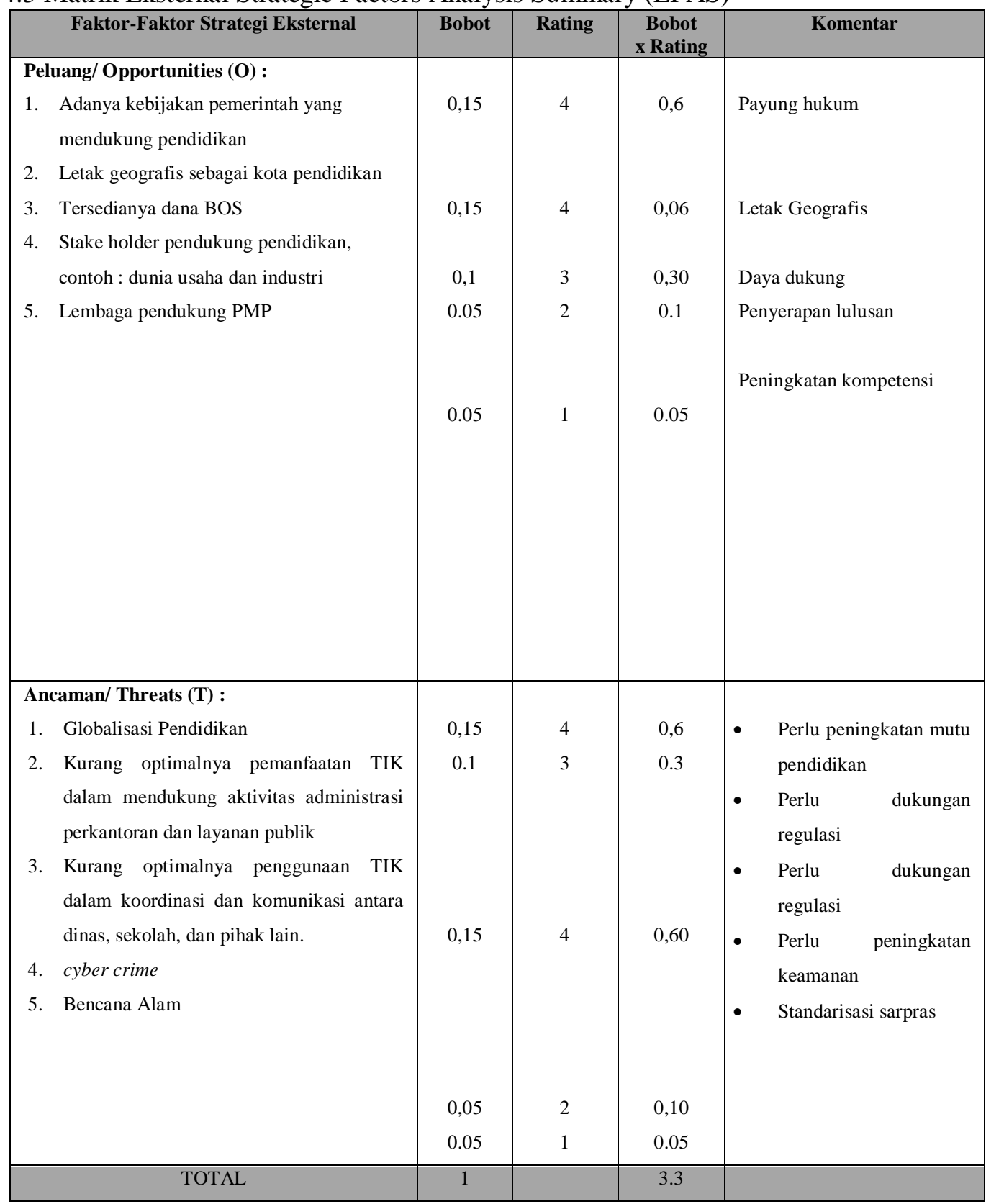

Jumlah scoring menunjukkan bahwa total IFAS sebesar 3.0 dan total EFAS sebesar 3,30 maka masuk ke dalam kuadran I (satu) pada tabel 4.6 yaitu pertumbuhan Strategi konsentrasi melalui integrasi vertical..

Tabel 4.6 Matriks Internal - Eksternal 
Faktor Internal (IFE)

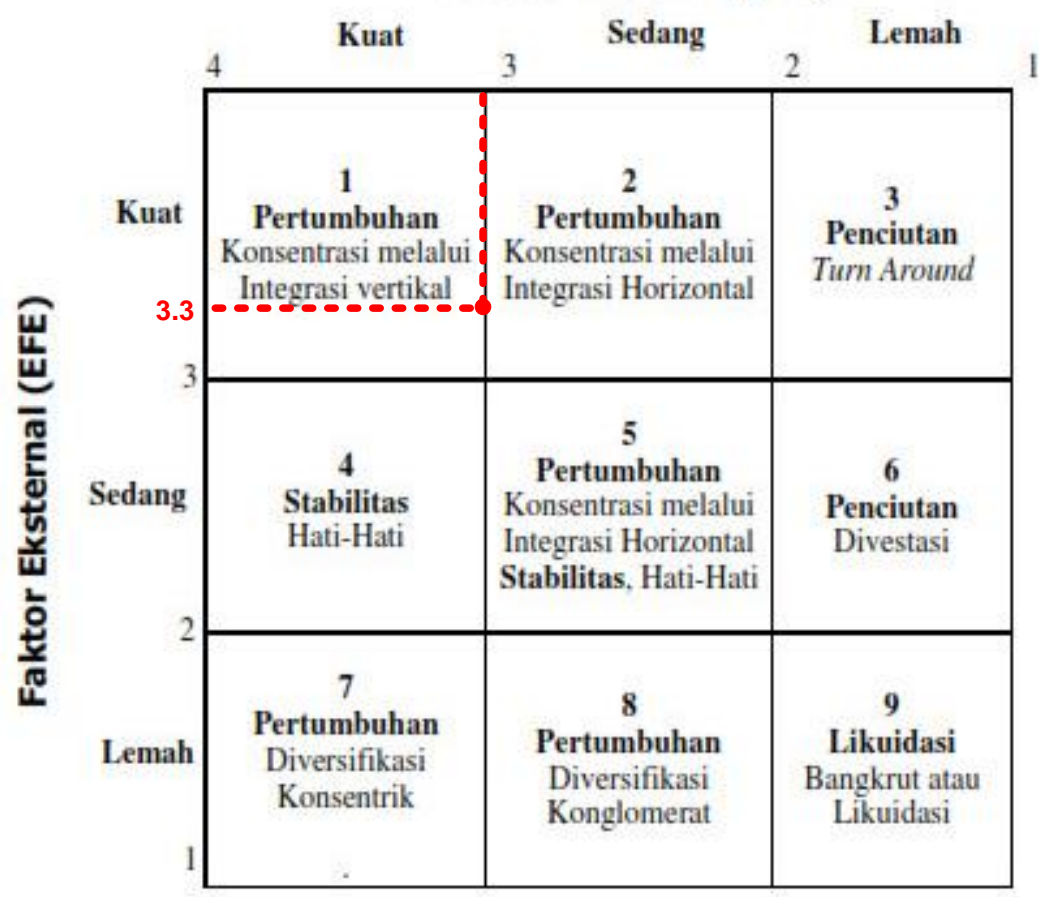

Berdasarkan matrik IFAS dan EFAS di atas, maka dilakukan analisis untuk mencari strategi dengan menggunakan kekuatan yang ada untuk memanfaatkan peluang yang tersedia (strategi S-O) serta menggunakan kekuatan yang dimiliki untuk mengatasi ancaman yang ada (strategi S-T). Selain itu dianalisis pula strategi untuk mengurangi kelemahan yang dimiliki dalam meraih peluang yang ada (strategi $\mathrm{W}-\mathrm{O}$ ) maupun mengatasi ancaman yang ada (strategi $\mathrm{W}$ T). Pemetaan strategi S-O, S-T, dan W-O, W-T dapat dilihat pada tabel 4.7 dan tabel 4.8 pada halaman berikut.

Tabel 4.7 Strategi S-O dan S-T

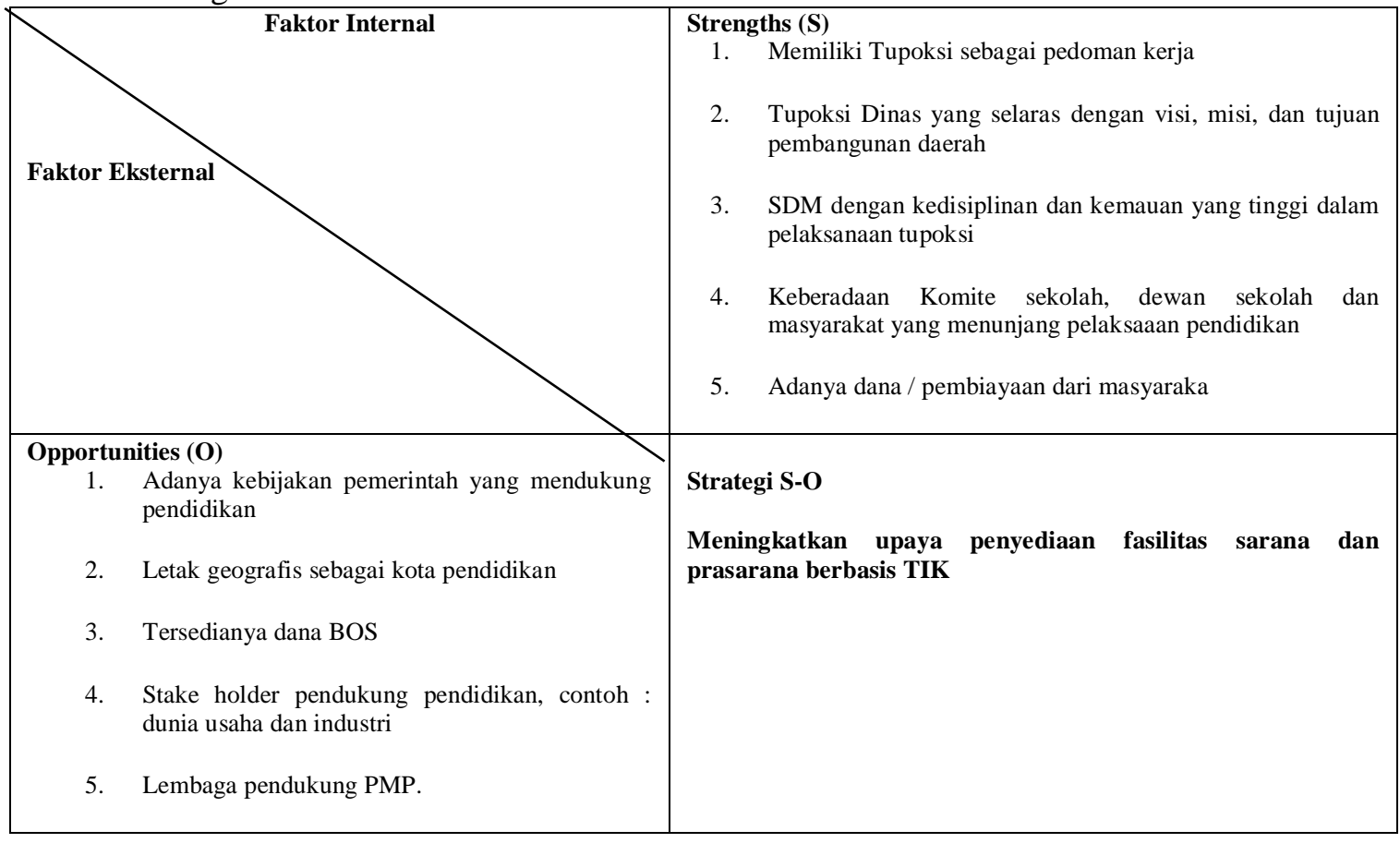


VOL: 1 NO: 1

\begin{tabular}{|cl|l|}
\hline $\begin{array}{c}\text { Threats (T) } \\
\text { 1. } \quad \text { Globalisasi Pendidikan }\end{array}$ & Strategi S-T \\
2. $\quad \begin{array}{l}\text { Kurang optimalnya pemanfaatan TIK dalam } \\
\text { mendukung aktivitas administrasi perkantoran. }\end{array}$ & $\begin{array}{l}\text { Merekomendasikan penyusunan peraturan agar komunikasi } \\
\text { dan kerjasama dapat dilakukan dengan memanfaatkan TIK. }\end{array}$ \\
3. $\begin{array}{l}\text { Kurang optimalnya penggunaan TIK dalam } \\
\text { koordinasi dan komunikasi antara dinas, sekolah, } \\
\text { dan pihak lain. }\end{array}$ & \\
4. $\quad \begin{array}{l}\text { cyber crime } \\
\text { 5. } \quad \text { Bencana Alam. }\end{array}$ & \\
\hline
\end{tabular}

Tabel 4.8 Strategi W-O dan W-T

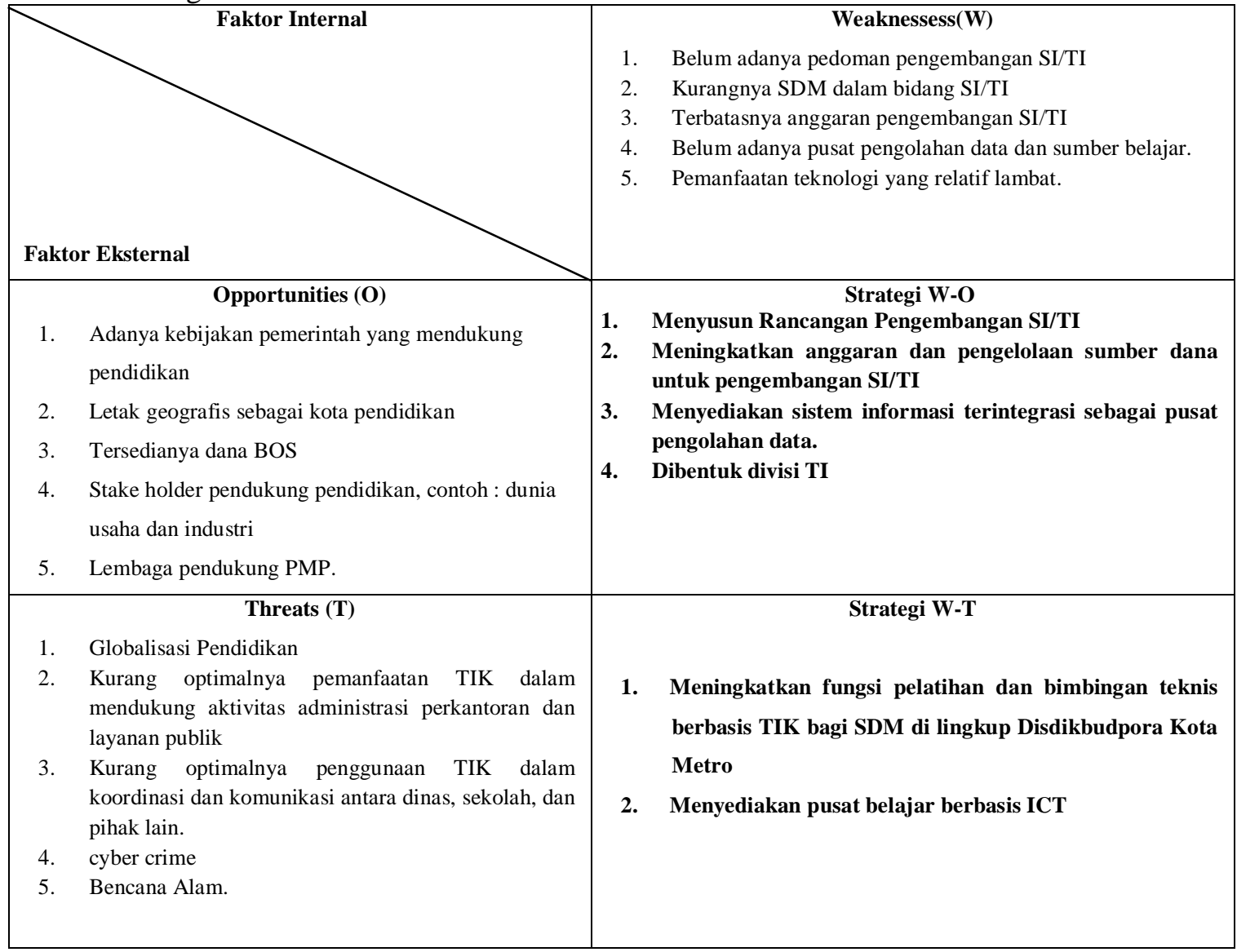


VOL: I NO: 1

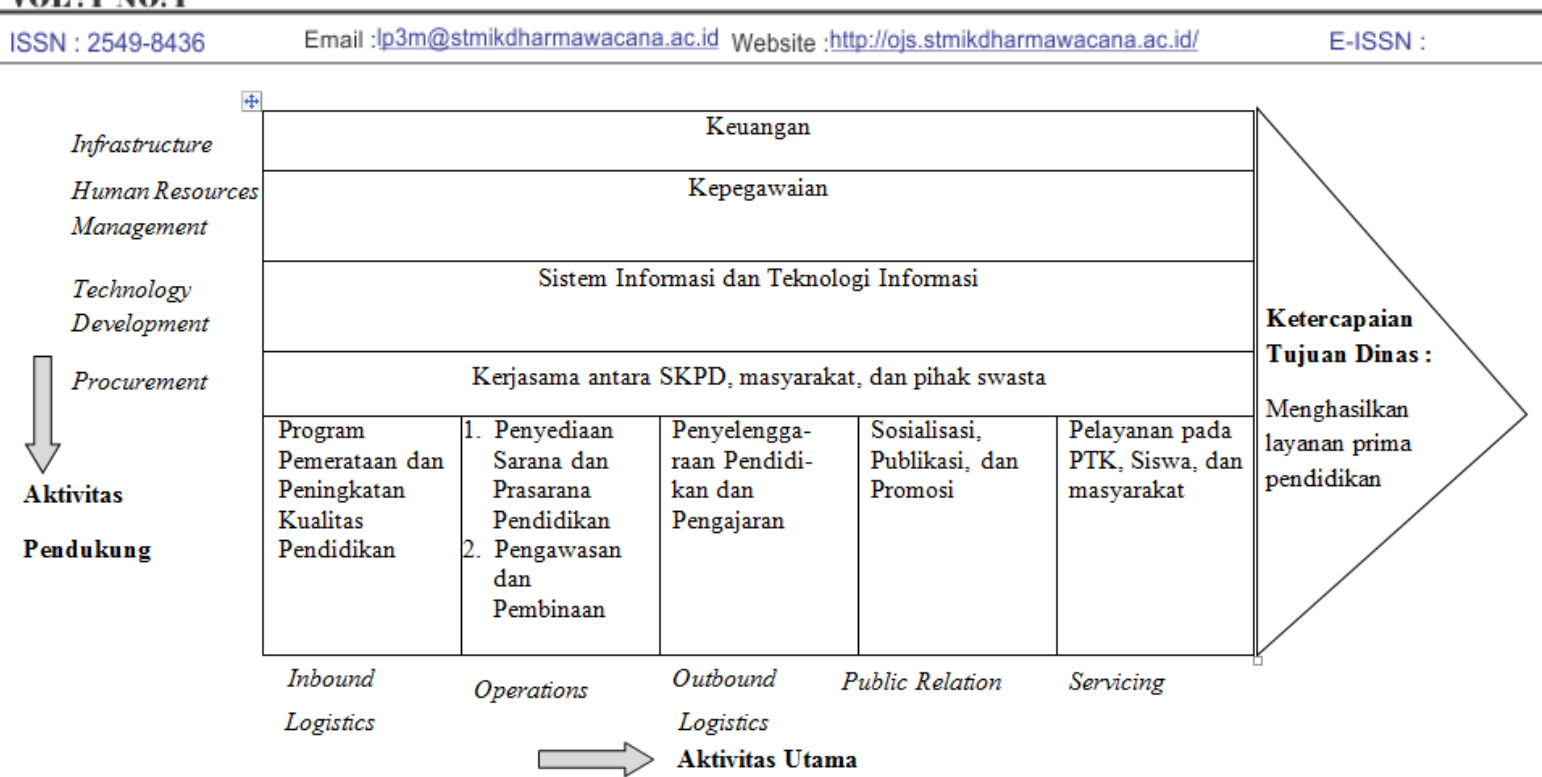

Gambar 4.1 Value Chain Dinas Pendidikan Kebudayaan Pemuda dan Olahraga Kota Metro

\subsection{Analisis Lingkungan Bisnis Eksternal}

Secara umum lingkungan eksternal organisasi dapat diidentifikasi melalui analisa Politik, Ekonomi, Sosial dan Teknologi (PEST). Analisis Pest dilakukan untuk mengetahui kejadian luar dari Disdikbupora Kota Metro yang mempengaruhi proses bisnis disdikbudpora.

\subsubsection{Aspek Politik}

Dinas Pendidikan Kebudayaan Pemuda dan Olahraga Kota Metro dalam melakukan tugastugasnya dipertanggung jawabkan dan dikoordinasikan oleh Kementrian Pendidikan dan Kebudayaan untuk penyelenggaraan pendidikan.Selain itu disdikbudporan juga bertanggung jawab kepada pemerintah kota metro sebagai sebuah SKPD. Kebijakan Pemerintah pusat dalam peningkatan anggaran pendidikan sebesar $20 \%$ dan juga arah tujuan pengembangan kota Metro sebagai kota pendidikan menjadikan hal ini menjadi peluang bagi disdikbudpora Kota Metro untuk dapat mengembangkan proses bisnis.nya.

Untuk itu Disdikbudpora kota metro harus dapat mempertimbangkan perubahan kebijakan terkait dengan pemanfaatan kebijakan anggaran yang ditentukan dari APBD pemerintah kota metro

\subsubsection{Aspek Ekonomi}

Peningkatan pendapatan masyarakat mengakibatkan para orang tua menginginkan anaknya mendapatkan pendidikan terbaik. Faktor jarak sudah bukan menjadi penghalang untuk menempuh pendidikan. Hal ini dapat menjadi ancaman bagi pendidikan disdikbudpora dikarenakan factor geografinya yang relative dekat dengan Metro sebagai pusat kota dan sebagai pesaing dalam hal pelayanan pendidikan.

\subsubsection{Aspek Sosial}

Faktor yang berpengaruh dalam aspek ini adalah dengan daya tarik Kota Metro sebagai kota pendidikan membuat semakin banyaknya penduduk musiman yang menetap di kota Metro. Hal tersebut dapat menjadi ancaman ataupun peluang bagi Disdikbudpora. Faktor ancaman dikarekan faktor gaya hidup penduduk musiman dapat mempengaruhi cara orang hidup, belajar, dan bekerja.

\subsubsection{Aspek Teknologi}

Revolusi teknologi akan berpengaruh besar terhadap organisasi. Perkembangan teknologi mobile membuat mayoritas orang akan dapat mengakses informasi pendidikan dengan lebih 
VOL: 1 NO: 1

cepat. Ancaman yang muncul dari aspek ini adalah kurangnya kompetensi PTK untuk pemanfaatan teknologi.

Tabel 4.9 Analisis PEST

\begin{tabular}{|c|c|c|c|}
\hline Faktor & $\begin{array}{l}\text { Ancaman/ } \\
\text { Peluang }\end{array}$ & Inisiatif & $\begin{array}{c}\text { Kebutuhan } \\
\text { SI/TI }\end{array}$ \\
\hline Politik & $\begin{array}{l}\text { Kebijakan angaran } \\
\text { pendidikan } \\
\text { sebesar } 20 \%\end{array}$ & $\begin{array}{l}\text { Mempertimbangkan } \\
\text { perubahan kebijakan dan } \\
\text { perubahan anggaran yang } \\
\text { disesuakan dengan PAD } \\
\text { Kota Metro }\end{array}$ & $\begin{array}{l}\text { SI RAPBS } \\
\text { (sudah } \\
\text { tersedia) }\end{array}$ \\
\hline Ekonomi & $\begin{array}{l}\text { Peningkatan } \\
\text { pendapatan } \\
\text { masyarakat }\end{array}$ & $\begin{array}{l}\text { Meningkatkan publikasi } \\
\text { keunggulan pendidikan } \\
\text { kota metro }\end{array}$ & $\begin{array}{l}\text { Website } \\
\text { dinas } \\
\text { pendidikan } \\
\text { dan sekolah }\end{array}$ \\
\hline Sosial & $\begin{array}{l}\text { Bertambahnya } \\
\text { penduduk } \\
\text { musiman dapat } \\
\text { mempengaruhi } \\
\text { cara orang belajar }\end{array}$ & $\begin{array}{l}\text { Membuat kebijakan jam } \\
\text { wajib belajar dan } \\
\text { mensosialisasikan kepada } \\
\text { masyarakat }\end{array}$ & - \\
\hline Teknologi & $\begin{array}{l}\text { Pemanfaatan } \\
\text { teknologi }\end{array}$ & $\begin{array}{l}\text { Pelatihan pemanfaatan } \\
\text { TIK }\end{array}$ & $\begin{array}{l}\text { Learning } \\
\text { Management }\end{array}$ \\
\hline
\end{tabular}

\subsection{Analisis Lingkungan SI/TI Internal}

Analisis lingkungan SI/TI dari organisasi dilakukan untuk memperoleh gambaran SI/TI organisasi Dinas Pendidikan Kebudayaan Pemuda dan Olahraga Kota Metro saat ini, meliputi perangkat komputer hardware dan software, aplikasi-aplikasi yang digunakan dan sistem operasi.

Tabel 4.10 Portofolio SI/TI Disdikbudpora Saat Ini

\begin{tabular}{|c|c|}
\hline STRATEGIC & HIGH POTENTIAL \\
\hline & $\begin{array}{l}\text { Sasaran Kerja Pegawai (dalam } \\
\text { pengembangan) }\end{array}$ \\
\hline KEY OPERATIONAL & SUPPORT \\
\hline $\begin{array}{l}\text { - } \quad \text { RAPBS (Rencana anggaran pendapatan } \\
\text { dan belanja sekolah) }\end{array}$ & $\begin{array}{ll}\text { - } & \text { SI Peneriman Peserta Didik } \\
& \text { Baru (PPDB) } \\
\text { - } & \text { Web disdikbudpora } \\
\text { - } & \text { Aplikasi office automation dan } \\
& \text { webmail } \\
\text { - } & \text { E-Surat } \\
\text { - } & \text { PPID }\end{array}$ \\
\hline
\end{tabular}

\subsection{Analisis Gap Kebutuhan Informasi}

Analisis ini digunakan untuk mengetahui kesenjangan (gap) antara identifikasi permasalahan utama data pendidik dan kependidikan di disdikbudpora kota metro dengan kebutuhan informasi yang akan datang. 
VOL: 1 NO: 1

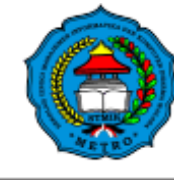

ISSN : 2549-843

Email:1p3m@stmikdharmawacana.ac.id Website :http://ojs.stmikdharmawacana.ac.id/

E-ISSN :

Tabel 4.11 Analisis Kesenjangan (Gap) dan Sasaran

\begin{tabular}{|c|c|c|c|c|c|}
\hline Fokus & $\begin{array}{l}\text { Sumber } \\
\text { Masalah }\end{array}$ & $\begin{array}{c}\text { Kondisi Saat } \\
\text { Ini }\end{array}$ & $\begin{array}{c}\text { Kondisi Masa } \\
\text { Datang }\end{array}$ & Kesenjangan & Sasaran \\
\hline $\begin{array}{l}\text { Pengumpulan } \\
\text { Data }\end{array}$ & $\begin{array}{l}\text { Belum ada } \\
\text { fasilitas } \\
\text { pengumpulan } \\
\text { data berbasis } \\
\text { TIK }\end{array}$ & $\begin{array}{l}\text { Pengumpulan } \\
\text { data manual }\end{array}$ & $\begin{array}{l}\text { Memaksimalkan } \\
\text { fasilitas } \\
\text { pengumpulan data } \\
\text { secara online } \\
\text { untuk kebutuhan } \\
\text { administrasi dan } \\
\text { statistik } \\
\text { kependidikan }\end{array}$ & $\begin{array}{ll}\text { 1. } & \text { Belum dapat } \\
\text { berkoordinasi } \\
\text { dengan baik } \\
\text { 2. } & \text { Belum } \\
& \text { maksimalnya } \\
\text { pelayanan } \\
\text { publik }\end{array}$ & $\begin{array}{l}\text { Sistem } \\
\text { Pengumpulan data } \\
\text { pendidikan yang } \\
\text { mudah dipahami } \\
\text { dan digunakan } \\
\text { untuk pelaporan } \\
\text { data secara cepat, } \\
\text { tepat, akurat dan } \\
\text { periodik }\end{array}$ \\
\hline Analisis Data & $\begin{array}{l}\text { Belum ada } \\
\text { sistem analisis } \\
\text { data berbasis } \\
\text { TIK }\end{array}$ & $\begin{array}{l}\text { Analisis data } \\
\text { manual dari } \\
\text { satuan } \\
\text { pendidikan dan } \\
\text { dilanjutkan ke } \\
\text { unit-unit di } \\
\text { disdikbudpora }\end{array}$ & $\begin{array}{l}\text { Sistem informasi } \\
\text { terintegrasi } \\
\text { berbasis website } \\
\text { untuk memenuhi } \\
\text { kebutuhan } \\
\text { administrasi dan } \\
\text { pembelajaran }\end{array}$ & $\begin{array}{ll}\text { - } & \text { Akses sumber data } \\
\text { dan informasi } \\
\text { terbatas } \\
\text { - } & \text { PTK yang masih } \\
\text { belum merata }\end{array}$ & $\begin{array}{l}\text { Adanya sistem } \\
\text { yang memudahkan } \\
\text { analisa data } \\
\text { pendidikan agar } \\
\text { bisa merealisasikan } \\
\text { hasil dengan } \\
\text { sasaran pendidikan } \\
\text { dengan hasil yang } \\
\text { akurat dan cepat } \\
\text { sehingga } \\
\text { mendukung } \\
\text { perumusan } \\
\text { kebijakan dan } \\
\text { membantu dalam } \\
\text { perkiraan } \\
\text { kebutuhan. }\end{array}$ \\
\hline Tenaga Kerja & $\begin{array}{l}\text { Kurangnya } \\
\text { kompetensi } \\
\text { SDM dalam } \\
\text { pemanfaatan } \\
\text { TIK }\end{array}$ & $\begin{array}{l}\text { SDM } \\
\text { kepegawaian } \\
\text { dan SDM PTK } \\
\text { di tiap satuan } \\
\text { pendidikan } \\
\text { masih kurang } \\
\text { dalam } \\
\text { pemahaman } \\
\text { dan penerapan } \\
\text { perkembangan } \\
\text { TIK }\end{array}$ & $\begin{array}{l}\text { Pengelolaan dan } \\
\text { pengembangan } \\
\text { aplikasi sistem } \\
\text { informasi } \\
\text { terintegrasi }\end{array}$ & 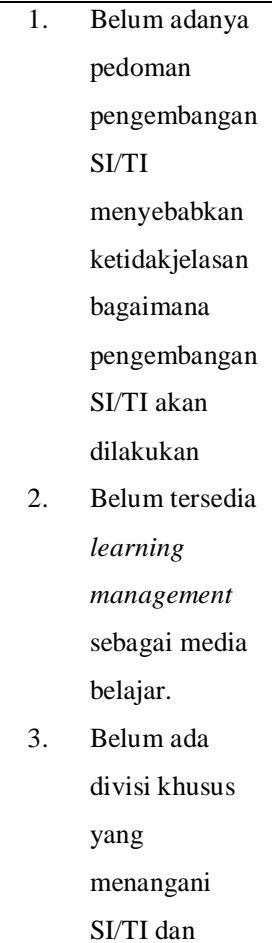 & $\begin{array}{ll}\text { 1. } & \text { Pembuatan } \\
& \text { pedoman } \\
& \text { pengembanga } \\
& \text { n SI/TI } \\
\text { 2. } & \text { Sistem } \\
& \text { pembelajaran } \\
\text { online } \\
\text { Pembentukan } \\
\text { divisi SI/IT }\end{array}$ \\
\hline
\end{tabular}




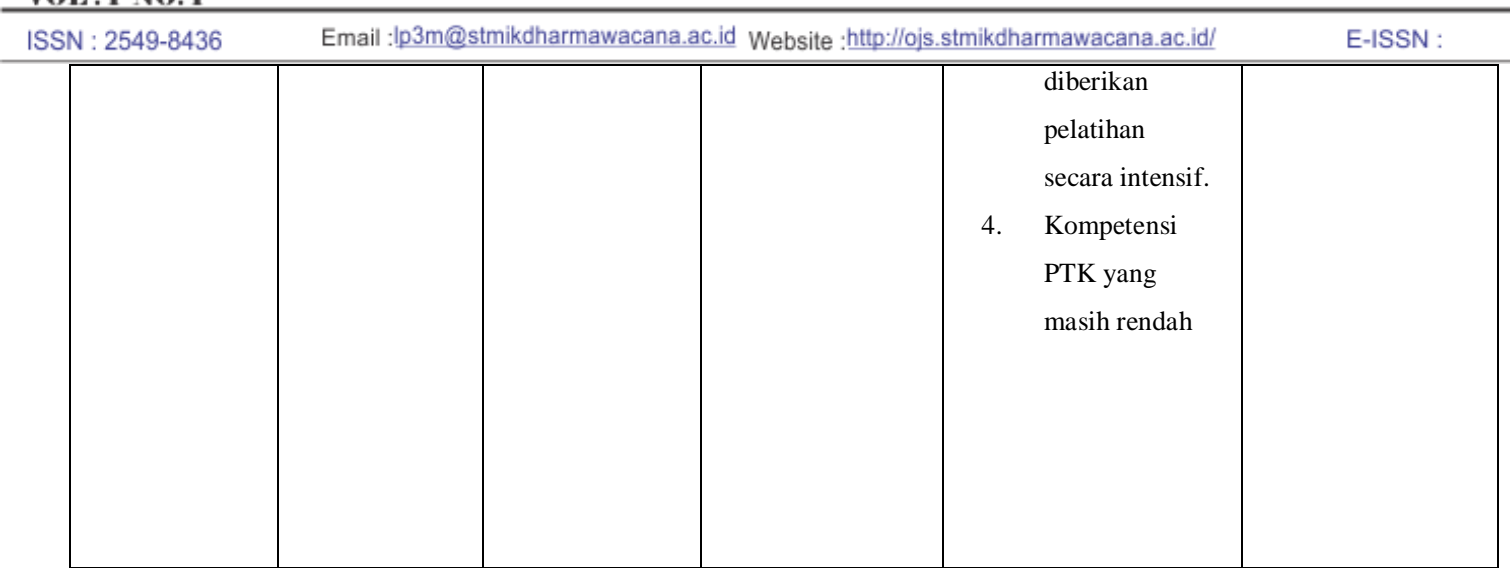

Tabel 4.12 Analisis Kebutuhan Informasi Untuk Pemerataan dan Peningkatan SDM PTK

\begin{tabular}{|c|c|c|c|c|}
\hline Tujuan & CSF & Ukuran & Strategi SWOT & Kebutuhan Informasi \\
\hline $\begin{array}{l}\text { Pemerataan } \\
\text { dan } \\
\text { Peningkatan } \\
\text { SDM PTK }\end{array}$ & $\begin{array}{l}\text { - } \text { Rasio Guru } \\
\text { - Sertifikasi } \\
\text { dan } \\
\text { kualifikasi } \\
\text { tenaga } \\
\text { pendidik } \\
\text { - } \text { Tersedianya } \\
\text { pusat belajar } \\
\text { berbasis TIK }\end{array}$ & $\begin{array}{l}\text { Meningkatnya } \\
\text { ketersediaan tenaga } \\
\text { pendidik PAUD, TK, SD, } \\
\text { SMP, SMA/SMK yang } \\
\begin{array}{l}\text { bersertifikasi dan } \\
\text { berkualifikasi. }\end{array}\end{array}$ & 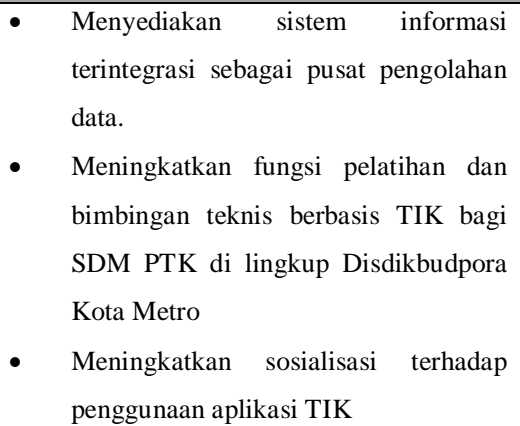 & \begin{tabular}{|ll}
- & Informasi SDM \\
& PTK \\
- & Informasi \\
& Pengembangan \\
& Keprofesian \\
& Berkelanjutan \\
& (PKB) \\
- & Pusat Belajar \\
& berbasis TIK
\end{tabular} \\
\hline
\end{tabular}

Tabel 4.13 Analisis Kebutuhan Informasi Untuk Peningkatan Kualitas Sarana-Prasarana Pendidikan

\begin{tabular}{|c|c|c|c|c|}
\hline Tujuan & CSF & Ukuran & Strategi SWOT & Kebutuhan Informasi \\
\hline $\begin{array}{l}\text { Meningkatkan } \\
\text { kualitas sarana- } \\
\text { prasarana } \\
\text { pendidikan }\end{array}$ & $\begin{array}{l}\text { Jumlah sarana- } \\
\text { prasarana } \\
\text { pendidikan }\end{array}$ & $\begin{array}{l}\text { Bertambahnya sarana- } \\
\text { prasarana pendidikan } \\
\text { berkualitas }\end{array}$ & $\begin{array}{ll}\text { - } & \text { Meningkatkan upaya penyediaan } \\
\text { fasilitas sarana dan prasarana } \\
\text { pendidikan berbasis TIK } \\
\text { Meningkatkan anggaran dan } \\
\text { pengelolaan sumber dana untuk } \\
\text { pengembangan SI/TI. } \\
\text { Menyediakan sistem informasi } \\
\text { terintegrasi sebagai pusat } \\
\text { pengolahan data } \\
\text { Membentuk Divisi SI/TI }\end{array}$ & $\begin{array}{ll}\text { - } & \text { Informasi data } \\
\text { sekolah dan } \\
\text { Manajemen Aset }\end{array}$ \\
\hline
\end{tabular}

Tabel 4.14 Analisis Kebutuhan Informasi Untuk Peningkatan Kualitas Manajemen Pendidikan

\begin{tabular}{|c|c|c|c|c|}
\hline Tujuan & $\mathrm{CSF}$ & Ukuran & Strategi SWOT & Kebutuhan Informasi \\
\hline $\begin{array}{l}\text { Meningkatkan } \\
\text { kualitas } \\
\text { manajemen } \\
\text { pendidikan }\end{array}$ & $\begin{array}{l}\text { Penguatan } \\
\text { Manajemen } \\
\text { satuan } \\
\text { pendidikan }\end{array}$ & $\begin{array}{l}\text { Penguatan kualitas } \\
\text { manajemen } \\
\text { lembaga/satuan } \\
\text { pendidikan formal dan } \\
\text { non formal } \\
\text { - } \\
\text { Peningkatan mutu } \\
\text { layanan pendidikan }\end{array}$ & $\begin{array}{ll}\text { - } & \text { Merekomendasikan penyusunan } \\
\text { peraturan himbauan agar komunikasi } \\
\text { dan kerjasama dapat dilakukan } \\
\text { dengan memanfaatkan TIK } \\
\text { - } \\
\text { Menyusun Rancangan } \\
\text { Pengembangan SI/TI }\end{array}$ & $\begin{array}{l}\text { - Informasi Data } \\
\text { siswa dan } \\
\text { Akademik }\end{array}$ \\
\hline
\end{tabular}


VOL: 1 NO: 1

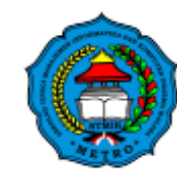

ISSN : 2549-8436

\subsection{Konsep Rancangan SI/TI}

Konsep rancangan aplikasi sistem informasi tersebut diarahkan dengan membangun aplikasi yang membaginya menjadi dua bagian, yaitu bagian yang menyediakan interface kepada user dan bagian yang memproses dan menyimpan data ke dalam database. Aplikasi yang akan digunakan dalam menerapkan konsep tersebut digunakan aplikasi dengan model web-based.

\subsubsection{Aplikasi Data Pendidikan}

Aplikasi ini merupakan Sistem Informasi terintegrasi berbasis web yang dapat diakses oleh beberapa pengguna dengan hak akses berbeda. Tampilan usulan beranda adalah sebagai berikut

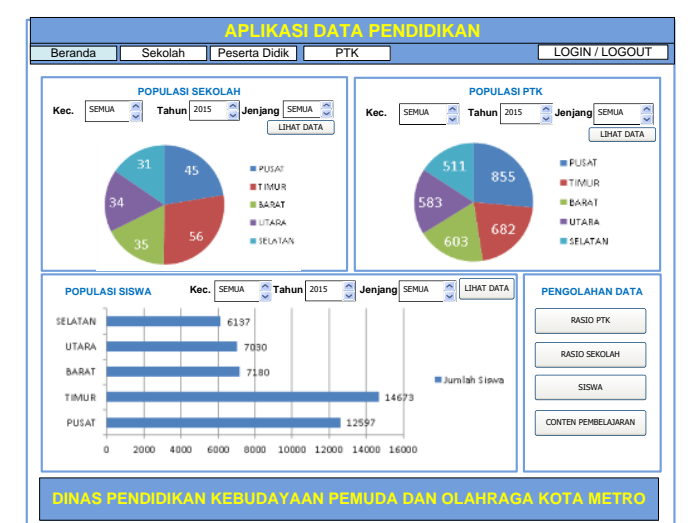

Gambar 4.2 Usulan Aplikasi Data Pendidikan

\subsubsection{Usulan Konfigurasi Jaringan Komputer}

Usulan konfigurasi infrastruktur jaringan komputer di Dinas Pendidikan Kebudayaan Pemuda dan Olahraga Kota Metro adalah sistem jaringan terintegrasi yang tidak melupakan faktor keamanan dalam perencanaannya.

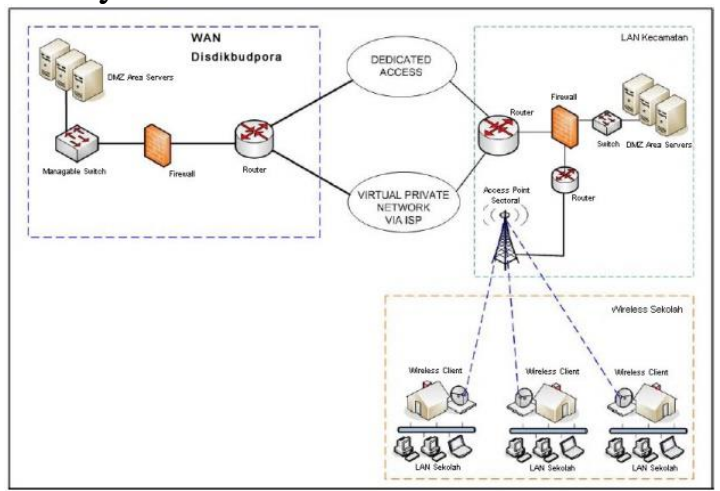

Gambar 4.3 Topologi Jaringan Usulan

\subsubsection{Rancangan Portofolio Mendatang}

Rancangan portofolio mendatang dilakukan dengan menggunakan matrik portofolio aplikasi McFarlan untuk mengetahui gambaran tentang kontribusi setiap aplikasi terhadap organisasi saat ini dan masa mendatang. Sebelum dipetakan ke dalam matrik McFarlan, terlebih dahulu dilakukan analisa berdasarkan tinggi atau rendahnya ketergantungan SI saat ini dan tinggi atau rendahnya kepentingan TI masa depan seperti yang dapat dilihat pada tabel 4.23 dejarat kepentingan SI/TI di bawah ini. 
VOL: 1 NO: 1

Tabel 4.15 Derajat Kepentingan SI/TI

\begin{tabular}{|c|l|c|c|c|c|}
\hline \multirow{2}{*}{ No } & \multicolumn{2}{|c|}{ Solusi SI/TI } & \multicolumn{2}{|c|}{$\begin{array}{c}\text { Current dependence } \\
\text { on IS }\end{array}$} & $\begin{array}{c}\text { Future importance } \\
\text { of IT }\end{array}$ \\
\cline { 3 - 6 } & & High & Low & High & Low \\
\hline 1 & SI Pemetaan Sekolah dan aset & $\sqrt{ }$ & & & $\sqrt{ }$ \\
\hline 2 & SI Siswa dan Akademik & $\sqrt{ }$ & & & $\sqrt{ }$ \\
\hline 3 & SI SDM PTK DAN PKB & $\sqrt{ }$ & & $\sqrt{ }$ & \\
\hline 4 & Learning management & $\sqrt{ }$ & & & $\sqrt{ }$ \\
\hline
\end{tabular}

Berdasarkan tabel derajat kepentingan SI/TI di atas selanjutnya dapat dikategorikan kemudian solusi SI/TI dimasukkan ke dalam tabel matrik McFarlan seperti yang dapat dilihat pada tabel 4.16 berikut.

Tabel 4.16 Kategori Portofolio SI/TI

\begin{tabular}{|c|c|c|c|c|}
\hline \multicolumn{2}{|c|}{ Current dependence on IS } & \multicolumn{2}{c|}{ Future importance of IT } & McFarlan \\
\hline High & Low & High & Low & Category \\
\hline$\sqrt{ }$ & & $\sqrt{ }$ & & Strategic \\
\hline$\sqrt{ }$ & & & $\sqrt{ }$ & Key Operational \\
\hline & $\sqrt{ }$ & $\sqrt{ }$ & & High Potential \\
\hline & $\sqrt{ }$ & & $\sqrt{ }$ & Support \\
\hline
\end{tabular}

Hasil Rancangan portofolio mendatang yang dihasilkan sesuai kategori matrik McFarlan seperti pada tabel 4.17 berikut.

Tabel 4.17 Portofolio SI/TI Disdikbudpora Kota Metro Yang Akan Datang

\begin{tabular}{|c|c|}
\hline STRATEGIC & HIGH POTENTIAL \\
\hline $\begin{array}{l}\text { - } \quad \text { SI SDM PTKdan PKB (Sumber daya manusia } \\
\text { Pendidik dan Tenaga Kependidikan \& } \\
\text { Pengembangan Keprofesian Berkelanjutan) }\end{array}$ & $\begin{array}{ll}\text { - } & \text { SI Pemetaan Sekolah (School Mapping) dan } \\
\text { - } & \text { Aset } \\
\text { Sasaran Kerja Pegawai (dalam } \\
\text { pengembangan) }\end{array}$ \\
\hline KEY OPERATIONAL & SUPPORT \\
\hline $\begin{array}{ll}\text { - } & \text { SI Siswa dan Akademik } \\
\text { - } & \text { Learning Management } \\
\text { - } & \text { RAPBS (Rencana anggaran pendapatan dan belanja } \\
& \text { sekolah) }\end{array}$ & $\begin{array}{ll}\text { - } & \text { SI Penerimaan Peserta Didik Baru (PPDB) } \\
\text { - } & \text { Web disdikbudpora } \\
\text { - } & \text { Aplikasi office automation dan webmail } \\
\text { - } & \text { E-Surat } \\
\text { - } & \text { PPID }\end{array}$ \\
\hline
\end{tabular}

\section{Kesimpulan Dan Saran}

\subsection{Kesimpulan}

Berdasarkan pembahasan dan uraian yang telah dilakukan pada bab-bab sebelumnya, maka dapat diambil kesimpulan sebagai berikut :

a. Dinas Pendidikan Kebudayaan Pemuda dan Olahraga Kota Metro saat ini belum maksimal dalam menerapkan SI/TI, baru sebatas tingkat pengolahan data secara manual, dan belum ada rencana induk penerapan SI/TI, namun komitmen untuk mendukung pemanfaatan SI/TI dalam peningkatan kinerja dinas dapat dilihat dari hasil wawancara yang dilakukan kepada kepala dinas 
b. Perancangan perencanaan strategis SI/TI pada Dinas Pendidikan Kebudayaan Pemuda dan Olahraga Kota Metro ini dilakukan dengan menggunakan metodologi Ward dan Peppard dengan tahapan melakukan analisa lingkungan bisnis internal dan eksternal organisasi, analisa SI/TI internal dan eksternal organisasi, dilanjutkan dengan proses identifikasi strategi, dan melakukan rancangan portofolio masa yang akan datang yang digunakan untuk membantu proses kerja organisasi dan pelayanan publik di lingkungan kantor.

c. Penyusunan perencanaan strategis SI/TI sesuai portofolio SI/TI yang dihasilkan dapat memberikan prioritas pada aktivitas yang dibutuhkan untuk memperoleh hasil yang optimal dan berdasarkan kontribusinya pada tujuan yang akan dicapai.

d. Hasil Rancangan Portofolio SI/TI mendatang berdasarkan pemetaan aplikasi matrik McFarlan yaitu pada kwadran strategic: SI SDM Pendidik dan Tenaga Kependidikan (PTK) \& Pengembangan Keprofesian Berkelanjutan (PKB),pada kwadran key operational: SI Data Siswa dan Akademik serta learning management, Sistem Informasi Peserta Didik, SI PKB (Pengembangan Keprofesian Berkelanjutan), pada kwadran high potensial: SI Pemetaan Sekolah dan Aset.

\subsection{Saran}

Dari semua pembahasan pada bab-bab sebelumnya serta analisa-analisa yang telah dilakukan, penulis memberikan saran :

a. Perencanaan strategis SI/TI ini sedapat mungkin dievaluasi pada rentang waktu tertentu, agar tetap selaras dengan perubahan bisnis organisasi dalam pencapaian tujuan organisasi.

b. Pada setiap tahap implementasi, sebaiknya setelah dilakukan pelatihan dilakukan evaluasi pelaksanaan implementasi.

c. Kebijakan keamanan SI/TI yang akan dibangun sebaiknya selalu memenuhi kebutuhan dasar keamanan sistem informasi yaitu: kerahasiaan, kendali akses, otentikasi, integritas dan tidak menyangkal pengiriman dan penerimaan file pada sistim jaringan.

d. Rencana strategis SI/TI yang telah dihasilkan diharapkan dapat digunakan sebagai masukkan dalam perencanaan strategis periode tahun mendatang di lingkungan Dinas Pendidikan Kebudayaan Pemuda dan Olahraga Kota Metro, dan dapat dijadikan rujukan untuk melakukan penyusunan perencanaan strategis SI/TI Dinas Pendidikan bagi kabupaten lainnya.

\section{Daftar Pustaka}

Anggelina. 2012. Perencanaan Strategis Sistem Informasi Pada Direktorat Jenderal Peternakan Dan Kesehatan Hewan, Kementerian Pertanian. Laporan penelitian. Universitas Bina Nusantara. Jakarta

Bryson, John. 2007. Perencanaan Strategis bagi Organisasi Sosial.: Pustaka Belajar Offset. Yogyakarta

Gates, L.P., 2010. Strategic Planning with Critical Success Factors and Future Scenarios: An Integrated Strategic Planning Framework, Carniege Mellon University. Http://www.sei.cmu.edu, diakses pada 8 Februari 2015 
Handayaningrat, Soewarno.1988. Administrasi Pemerintahan dalam Pembangunan. Jakarta : Haji Mas Agung

Hariadi, B. 2003. Strategi manajemen, (cetakan pertama). Penerbit Bayu Media, Malang.

Anonim. Petunjuk Teknis Pelaksanaan Peraturan Bersama tentang Penataan dan Pemerataan Guru-PNS,

www.kopertis12.or.id/wp-content/uploads/012/01/juknis-peraturan-bersama-lima-menteritentang-penataan-pemerataan-guru-pns.pdf,

diakses pada tanggal 8 Maret 2015.

Mustakini, J. H. 2008. Metodologi Penelitian Sistem Informasi, Penerbit Andi Yogyakarta.

Mustakini, J. H. 2009. Sistem Informasi Teknologi-Edisi III . Yogyakarta: Andi Offset .2009

Rangkuti, F. 2004. Analisis SWOT Teknik Membedah Kasus Bisnis. PT. Gramedia Pustaka Utama, Jakarta

Rangkuti, F. 2013 Swot Balanced Scorecard: Teknik menyusun Strategi Korporat yang Efektif plus Cara Mengelola Kinerja dan Risiko Cetakan Keempat. Jakarta. Gramedia Pustaka Utama.

Sawitri, P. 2007. Strategi operasi.http://peni.staff.gunadarma.ac.id/ downloads/ files/ 3877/Strategi operasi (diakses tanggal 10 Januari 2012 Pukul 21.00 WIB.

Sihombing, Robert. 2012. Perencanaan Strategis Sistem Informasi dan Teknologi Informasi pada Dinas Pendidikan Kebudayaan dan Pariwisata Kabupaten Pringsewu. Laporan penelitian. Metro Dharma Wacana.

Ward, J., \& Peppard, J. 2002. Strategic Planning for Information Systems. John. Wiley \& Sons Ltd. London

Wedhasmara, Ari. 2009. Langkah-Langkah Perencanaan Strategis Sistem Informasi dengan Metode Ward and Peppard. Jurnal Sistem Informasi. ISSN: 2085-1588 H.14-22.

Widyaningsih, P. 2012. Perencanaan Strategis Sistem Informasi Pada Institusi Pendidikan Tinggi Menggunakan Analisis Critical Success Factors (Studi Kasus : Stmik Duta Bangsa Surakarta), Laporan penelitian. Pascasarjana Universitas Diponegoro. Semarang. 